\title{
Sobre la filosofia de la religión en América Latina
}

\author{
ENZO SOLARI \\ Universidad Católica del Norte, Chile
}

RESUMEN: El presente texto -versión ampliada de una conferencia que dictó el autor el 29 de septiembre de 2004 en la UCA de San Salvador - recoge algunos planteamientos críticos acerca de la filosofía de la religión en América Latina. Se plantea la necesidad de superar algunas insuficiencias en los planteamientos de autores representativos de la filosofía de la liberación, como Dussel, Kusch y Scannone. En cambio, la filosofía de la religión más rigurosa proviene de una vertiente que no se ba tomado en suficiente consideración: la filosofía fenomenológica. Esta propuesta, que proviene del pensamiento zubiriano, ba tenido importantes reinterpretaciones en autores como Ignacio Ellacuria y Antonio González.

Hace algún tiempo defendí estas hipótesis: primero, que la filosofía de la religión en la América de habla hispana no ha pasado de intentos fragmentarios, por lo general carentes de sistematicidad, precisión y exhaustividad; y segundo, que la más desarrollada filosofía de la religión en Hispanoamérica es aquella filosofía fenomenológica que depende de Zubiri. Volveré una vez más sobre ambas hipótesis, pero intentando recorrer otras vías para justificar su plausibilidad. 


\section{La religión en la filosofía de la liberación}

Comenzaré contrastando la primera hipótesis con dos de las formas más notorias de filosofía de la liberación desarrolladas entre nosotros. Me refiero a las filosofías surgidas en los años 60 y 70 , unas caracterizables por su énfasis ético-cultural, y otras basadas (más o menos intensamente) en el marxismo. De hecho, ambas pueden considerarse como las dos manifestaciones principales de dicha filosofía de la liberación. Y es que, cuando se atiende a la mediación utilizada, puede afirmarse que los autores que cultivan esta filosofía se orientan o bien por el empleo de un instrumental preferentemente hermenéutico (simbólico y sapiencial), o bien por el uso de categorías sobretodo marxistas (económicas y políticas) ${ }^{1}$.

1. Empecemos por aquella filosofía de la liberación cuya principal mediación es el marxismo. Nos encontramos aquí con una serie de autores que al hacer filosofía emplean categorías típicamente marxistas. Por cierto, los resultados a los que se arriba no son necesariamente comunes o coincidentes. Hay discrepancias en lo que hay de aprovechable para una filosofía latinoamericana dentro de la tradición marxista. Sea de ello lo que fuere, uno de los autores más influyentes de esta corriente es Enrique Dussel. Como veremos, este filósofo lleva a cabo alguna filosofía de la religión. Expongamos brevemente sus ideas.

En un texto publicado por primera vez en 1977 -cuyo destinatario es "el militante socialista revolucionario"2-, dice Dussel que "en esta corta obra se presentan sólo los límites dentro de los cuales se juega toda práctica religiosa. Entre la religión supraestructural y la religión infraestructural se abre el complejo campo religioso, con sus innumerables problemas propios. De todos ellos sólo hemos indicado dos: su límite supraestructural y su límite infraestructural extremos. Sin embargo, pretendemos que es por la religión infraestructural que la religión recibe su definición esencial"3.

Dussel añade a este texto un par de apéndices. Su mera lectura revela ya la dirección de esta investigación. Respecto de la religión supraestructural, las fuentes textuales de Dussel son, sobre todo, Hegel, Feuerbach, Marx, Engels, Luxemburgo, Lenin y Gramsci. También se menciona a la doctrina de la seguridad nacional e, incluso, a la religión en la declaración de la junta militar chilena (de 1974) ${ }^{4}$. En cuanto a la religión infraestructural, se acompañan textos del Antiguo y 
del Nuevo Testamento, de una obra de Fernando Belo sobre el evangelio de Marcos ${ }^{5}$, de Bartolomé de las Casas, Miguel Hidalgo y Costilla, Camilo Torres y Fidel Castro, la declaración de "Cristianos por el Socialismo" (de 1972), la declaración de teólogos del Tercer Mundo (de 1976) y la declaración del Comité Central del Partido Socialista Unido de Cataluña (de 1976) ${ }^{6}$. Es visible en Dussel la reunión del marxismo con la teología de la liberación. Este autor se ha concentrado en el pensamiento definitivo de Marx, particularmente en las cuatro redacciones de El Capital (de 1857 a 1880) recogidas en la II sección de las Obras Completas de Marx y Engels ${ }^{7}$. Y ha asumido la definición que de la teología ha brindado Gutiérrez ya desde su Teologia de la liberación de 1971: reflexión crítica de la praxis histórica a la luz de la fe en la palabra revelada. Así es como ha defendido no sólo la legitimidad de una utilización analítica (científica, social y económica) del marxismo originario - como han hecho los teólogos de la liberación y el mismo magisterio católico, por ejemplo en Laborem Exercens-, sino que ha abogado (influido por la teología de la economía de Hinkelammert) por su pleno empleo filosófico en el seno de la teología cristiana9.

Con este telón de fondo, se entiende que Dussel diga que la religión supraestructural es "la religión como supraestructura socio-cultural determinada por estructuras de dominación política (sobre las clases oprimidas, internamente, y sobre las minorías; y sobre los pueblos periféricos extranjeros) y económica (como bien lo indica Herberg: el del capitalismo monopólico internacional)"10. En contra de esta religión como supraestructura, es decir, como encubrimiento ideológico de la situación real de explotación económica, Dussel admite la posibilidad de una religión infraestructural, es decir, responsable y liberadora. Dice: "la religión puede [...] ser la expresión de la 'protesta contra la miseria real' [...]. Pero como mera protesta supraestructural no sería todavía religión en su sentido real. Sólo cuando además de protesta es praxis, es efectivo servicio al hermano oprimido, cuando es nueva política y nueva economía (y por ello nueva ideología y simbología), sólo entonces es auténtica religión, responsabilidad, culto al Infinito" 11 .

Luego, en un texto apenas tres años posterior al recién citado, Dussel reafirma estas ideas. Hay una contraposición esencial entre la religión fetichista y la religión liberadora, lo que supone - una vez 
más- la posibilidad de una ampliación de la explicación marxista de la función social de la religión. Dussel se asienta parcialmente en esa explicación de la religión, pero no acepta la pretensión de reducir los hechos religiosos a pura alienación. Dice Dussel que "el ego europeo, y posteriormente de todo el centro, constituye una Totalidad divinizada, fetichizada, la cual divinidad exige a los oprimidos de la periferia (y a los que se encuentran dentro del 'orden' divinizado: al niño, a la mujer y al trabajador), que le rindan un culto obligatorio. Ser ateos de una tal divinidad es la condición de posibilidad de rendir culto al Otro absolutamente absoluto, de cumplir una praxis de liberación"12. Respecto del fetichismo religioso piensa Dussel que hemos de ser rigurosamente ateos. Ésta es la condición de posibilidad de una fe religiosa completamente distinta, de una fe en el Otro absolutamente absoluto, una fe práctica, real, transformadora de los desórdenes materiales y culturales de este mundo: "la filosofía latinoamericana, entonces, no puede más que ser atea del 'dios-fetiche' de la modernidad, desde Descartes a Hegel o Heidegger [...]. El camino que hemos pretendido bosquejar [...] es de ortopraxia y no de ortodoxia: se trata de una vía meta-física para acceder a la realidad del Otro absolutamente absoluto, y no de una vía ontológica para de-mostrar su existencia. El discurso ortopráctico se apoya e indica el sentido de la praxis liberadora revolucionaria: es un argumento de realidad"13. De ahí también las referencias al ateísmo de los profetas y de Marx: tanto aquéllos como éste se dirigen contra el fetichismo, se trate de la idolatría de los paganos que no reconocen al Dios único y verdadero, se trate del ídolo moderno, el dinero ${ }^{14}$.

Mas, ya se advierte en Dussel no sólo la influencia de Marx y de la teología cristiana de la liberación, sino también la de Lévinas. La presencia de Lévinas es verdaderamente masiva en Dussel. Así se aprecia en los diversos intentos que hace Dussel por definir correctamente la religión. Veamos algunos de esos ensayos: "contra Hegel, que la describía como la elevación del finito al Infinito siendo esencialmente culto en la fe como acto representativo, la re-ligión es la ex-posición re-sponsable por el Otro ante el Otro absolutamente absoluto [...]. No se trata de la constitución de un cierto objeto como sagrado (como posición de la conciencia, por ejemplo, de un primitivo ante el tótem del clan, y tal como lo describe Otto), pero tampoco es una apertura al ser como divino. Se trata, en cambio, de una dimensión que está

\section{0}


antes que lo ontológico y más allá del ser: es anterior al a priori, es ligazón (como la de la obligación) al Otro, no sólo como interpelante o pro-vocante, sino como necesitante, suplicante, sufriente"15. Segundo ensayo: "la re-ligión o re-ligación metafísica es esa tensión anacrónica, inmemorial (anterior a toda historia), que expone al testigo y re-sponsable por el Otro, el pobre, ante el Otro absolutamente absoluto"16. Tercer ensayo: "el que se define como rehén en el sistema, gloria del Infinito y re-sponsable por el Otro, es el hombre religioso" ${ }^{17}$.

Para decirlo en pocas palabras, la de Dussel es una filosofía de la religión levantada sobre tres pilares: Marx, la teología de la liberación y Lévinas. Acabamos de verlo. La pregunta es si pueden compaginarse adecuadamente estas tres perspectivas. Pienso que no. Se trata de perspectivas esencialmente diversas: una crítica explicativa de la religión (la de Marx), la teología cristiana (en una versión liberadora) y una fenomenología ética como filosofía primera (la de Lévinas). La perspectiva fenomenológica, para empezar, debe ser evidente. La perspectiva explicativa, en cambio, no goza de evidencia alguna, y debe ser sometida a la contrastación empírica. Y la perspectiva teológica supone una participación creyente que no debería ser obligatoria para quien argumente dentro de los márgenes de la filosofía de la religión. Esto por lo que toca a la combinación de las tres perspectivas.

Si ahora consideramos autónomamente a estas perspectivas, se nos presentan otros problemas. La fenomenología inspirada en Lévinas es interesante y conduce a un exceso de significación, a una Alteridad irreductible que manda inapelablemente. Mas, ¿̇no es éste, en el fondo, un intento de 'filosoficar' lo que no es sino teología judía? Uno no puede dejar de preguntarse por el lugar que tendrían las demás religiones en esta particular concepción de la religión. Por lo mismo, ¿no nos enfrentamos a una disyuntiva parecida a la que establecía Barth entre religiones y fe? En este caso, se trataría de la diferencia entre el dios de la totalidad y el Otro infinito, o también entre mística y ética. En cuanto a la perspectiva crítica marxista, debemos ser cuidadosos. Frente a ella sólo disponemos del camino - siempre ecuménico- de la experiencia. Será ésta la que nos dirá si efectivamente la religión es alienación. Es decir, será necesario ver caso por caso si una religión cumple funciones falsificadoras o no. Puestos a teorizar, creo que una mejor explicación del hecho religioso es la que afirma 
una tendencia alienante en el seno de la religión, pero que admite a la vez la presencia (probablemente menos frecuente) de religiones o de factores religiosos que operan polémicamente contra el orden social constituido. Berger, por ejemplo, ha afirmado que la religión suele tener una función alienante, pues tiende a falsificar o duplicar la conciencia humana. Con mayor frecuencia estadística, las religiones llevarían al olvido de la dialéctica constante entre el yo y el mundo social y a la consiguiente naturalización de lo que no es más que historia y cultura dependiente de la actividad humana. Es la religión como proyección de significaciones en un más allá fatal, divino o sagrado. Empero, tal alienación no es necesaria a la religión. De hecho, pueden darse numerosos ejemplos (tanto en las religiones místicas cuanto en las proféticas) que muestran precisamente lo contrario: que la religión puede ser un factor de desalienación, o sea, de relativización, agitación y cuestionamiento de las estructuras sociales ${ }^{18}$. El mismo Dussel también estima posible una ampliación de la función social de la religión que reconozca en ella no sólo unas potencialidades alienantes, sino también otras liberadoras. Pero la suya es una argumentación teológica a favor de la religión. En Dussel esto se debe a la ligazón de la teoría marxista con la praxis y la teología de la liberación. Y acabamos de afirmar que ninguna teología puede aquí sernos de utilidad. Mas, no es fácil deslindar la empresa de Dussel de la existencia de cristianos marxistas y revolucionarios y, sobretodo, de la asunción de una teología que tematiza y justifica esa revolución ya acontecida o esperada. Ciertamente, hubiera sido preferible el recurso ecuménico a las ciencias sociales para obtener el mismo resultado, pero con mayores garantías de plausibilidad.

Por fin, no me cabe duda de que hay ideas marxistas aprovechables por parte de la filosofía de la religión y de la teología. Pero se tratará siempre y en todo caso de un uso inteligente, matizado, crítico. Aunque Dussel admite la diferencia, por ejemplo, entre marxismo y teología, y rechaza las versiones dogmáticas - estalinistas- de aquél, me parece con todo que es excesivamente optimista acerca de las posibilidades científicas, filosóficas y teológicas del marxismo: "los Padres de la Iglesia hicieron uso del platonismo, santo Tomás del aristotelismo, la teología de un Rahner, por ejemplo, del heideggerianismo. En el siglo XIX el uso de la 'ciencia' histórica causó la crisis del modernismo; y, sin embargo, hoy toda teología es 'histórica' - la crisis ha 
pasado-. De la misma manera acontecerá en el siglo XXI con el marxismo [...]. La obra de Franz Hinkelammert, Las armas ideológicas de la muerte [de 1977], desde una teología de la vida, abre nuevo camino. El uso del marxismo —en su nivel propio: económico y filosófico- es pleno, y asumido desde una fe cristiana que nada pierde de su propia tradición [...]. Por mi parte, en la obrita Ética comunitaria [de 1968], he intentado un discurso teológico cristiano, esencialmente bíblico, y, al mismo tiempo, estrictamente marxista [...]. La hipótesis epistemológica [de Ética comunitaria] es el uso sistemático de las categorías de Marx [...], con precisión estricta, y un uso de las categorías bíblicas en su sentido estricto hebreo, griego-cristiano"19. En estas afirmaciones se echa de menos una posición crítica no sólo con respecto a determinadas exposiciones usuales del marxismo, sino frente al propio pensamiento de Marx, en sus fuentes originales y a lo largo de su desarrollo. De manera análoga, Dussel salta por encima de los gravísimos problemas y abusos del socialismo soviético - que no se dejan resumir en un puro 'descenso de productividad' como motivo central de la crisis de este sistema-, del socialismo latinoamericano (el de Cuba y el de Nicaragua) y, más en general, de los diversos socialismos reales ${ }^{20}$. Es justo añadir que en la misma teología latinoamericana existen otras formas de concebir el recurso al marxismo. Por eso se ha hablado del riesgo de un "marxismo mal digerido"21.

2. Pasemos ahora a la filosofía de la liberación con énfasis culturalista. Uno de los representantes más puros de esta corriente culturalista es Rodolfo Kusch. Sus ideas son inconfundibles por afirmar la tajante peculiaridad, la diferencia fundamental de América Latina con respecto a Europa y en general a Occidente. Kusch dirá una y otra vez que en los pobladores populares e indígenas se halla la raíz, el fundamento más auténtico de América. El mestizaje habría consistido, entonces, en la superposición —más o menos conflictiva- de unas capas superficialmente europeas y modernas a ese núcleo primigenio. Por eso, aunque la vida americana se distanciaría por igual del utcatha del aymará (su 'estar en casa', 'domiciliado en el mundo') y del Dasein del occidental (el 'ahí del ser' de Heidegger), habría que afirmar que aquél representa "un ámbito previo" con relación a éste ${ }^{22}$. Ya al comienzo, a la hora de fijar el marco y las pretensiones de su investigación, Kusch reivindica la más completa alteridad de América. De ahí el carácter 'alternativo' de su proyecto ${ }^{23}$. Tanto es así que 
puede decirse que en América Latina conviven dos filosofías: "por un lado está la que aprendemos en la universidad y que consiste en una problemática europea traducida a nivel filosófico y, por el otro, un pensar implícito vivido cotidianamente en la calle o en el campo [...]. Claro está que no se trata de negar la filosofía occidental, pero sí de buscar un planteo más próximo a nuestra vida"24. Entre ambas filosofías, el estudioso de América ha de optar por ese pensar implícito, el cual, no obstante sus peculiaridades, sería plenamente capaz de universalizarse ${ }^{25}$.

Kusch, por cierto, intenta defenderse de las acusaciones de erigir una suerte de 'foklorismo' u 'ontologismo' americano. Por eso dice que en el pensar auténticamente americano existen posibilidades de universalización. Razón por la cual no sería legítima aquella acusación: "no se trata de un rabioso folklorismo filosófico. Se trata, antes bien, de captar libremente nuestra verdad sudamericana"26. Pero aunque Kusch reclame la universalidad de este pensamiento, prima incontestablemente en él la afirmación de la alteridad, de la exterioridad de la 'geocultura' americana. La América profunda es otra y pcsee una sabiduría original ${ }^{27}$. Ni el punto de vista 'científico' —de la sociología, la economía, el marxismo-, ni el del ideario democrático o religioso dicen nunca "realmente la verdad"28. Se trata de dos pensares distintos: "aceptemos, entonces, la hipótesis [...] que, frente a un pensar como el nuestro, se da un pensar indígena, y que ambos coexisten en Sudamérica" ${ }^{29}$. El pensamiento occidental -incluida no sólo la derecha liberal sino también la izquierda marxista- es causal y puede caracterizarse por su tendencia hacia la sociedad, la racionalidad (vinculada con la abstracción) y la soledad. El pensamiento indígena y popular, por el contrario, es seminal y tiende a la comunidad, la irracionalidad (vinculada con la tendencia hacia lo concreto) y el domicilio $^{30}$. En breve, Kusch enfrenta al objetivismo europeo-occidental con el subjetivismo o preobjetivismo de la población indígena y popular, particularmente del indio quechua, de los antiguos mexicanos, del papúa, e incluso del oriental, del budista y del hindú ${ }^{31}$.

Detengámonos en esta contraposición. Para la cultura europea, dice Kusch, el predicado es esencial. A él se subordina el sujeto como "a un orden superior y teórico, como ocurre en la lógica occidental”. Esta cultura "encuentra verdades inestables porque suprime la ira divina y crea un mundo material como la ciudad, la cual imita a la 
naturaleza”. Crea también la democracia, caracterizada por tener una "base inestable que depende del equilibrio interno entre los ciudadanos". Ella "se aísla del mundo, porque ha creado otro, integrado por maquinarias y objetos, que se superpone a la naturaleza". El suyo es "un mundo con objetos pero sin hombres o, mejor dicho, con ciudadanos que dejan de ser meros hombres para ser meras conductas, sin su trasfondo biológico". Es "una humanidad de sujetos o individuos" que se refugia en la ciudad. Es una cultura de la teoría y la ciencia, de la técnica y la industria, que son los modos europeos de enfrentar la hostilidad del mundo, la ira de dios. La de Europa es una cultura de llanura, una cultura ajena a la ira de dios e incluso - por haber perdido esa experiencia emocional- antagónica a ella ${ }^{32}$.

A esa cultura se contrapone la cultura americana en su núcleo más propio. Un caso ejemplar de esta otra sabiduría es la cultura quechua, estudiada por Kusch en América profunda. En ella, el sujeto es esencial, pues a él se subordinan todas las cualidades. El sujeto recibe pasivamente estas cualidades, sin resolverse ante ellas. El americano busca seguridad ante el mundo y "encuentra verdades estables" en el trato con la ira divina manifestada en la naturaleza. Su idea de gobierno "supone verdades estables". "Se sitúa en el mundo como siendo víctima de él". El suyo es "un mundo sin objetos y con sólo el hombre". Kusch precisa que el americano no es el género humano en abstracto, sino "la runacay o humanidad u hombre aquí" carente de individuos y que se refugia en el yo. Por eso ésta es una cultura de la conjuración y de la magia, que son los modos americanos de enfrentar la hostilidad del mundo, la ira de dios. La de América es una cultura de meseta, sumergida en la "ira de dios, la cual esconde una emoción mesiánica, que engendra un comportamiento espiritual”. Es una cultura "aprisionada por la gravidez de las cosas del mundo", por esa materialidad que es el marco de sus posibilidades de vida. La vida es en América la "pura vida", la "realidad pegada aún a nuestra carne" en la que "se funden los opuestos, dios y el diablo, miseria y pobreza, indios y porteños", civilización y barbarie ${ }^{33}$.

Seguramente puede apreciarse en esta tesis de la profundidad abisal de América una cierta metafísica y una cierta religiosidad. Tal metafísica es inseparable de la religiosidad, y viceversa. Partamos por la metafísica. La plástica contraposición que establece Kusch entre la pul- 
critud del ciudadano y el hedor del indio y del borracho ${ }^{34}$ manifiesta, en verdad, una contraposición más honda. Se trata de la idea de que mientras el europeo 'es', el americano 'está'. Una cosa sería el 'ser' o 'ser alguien' ("que descubro en la actividad burguesa de la Europa del siglo XVI"), y otra muy otra el 'estar' o 'estar aquí' o 'dejarse estar' o 'estar no más' ("que considero como una modalidad profunda de la cultura precolombina [...]") ${ }^{35}$. Ser es "un simple afán de ser alguien, una manera de destacarse en la competencia". Estar, en cambio, es el puro vivir, "el mero estar frente a la ira divina" 36 . El concepto de estar "logra concretar el verdadero estilo de vida de nuestra América, en la cual entrarían blancos y pardos, y ofrece, desde un punto de vista fenomenológico, una inusitada riqueza. Va implícito en dicho término esa peculiaridad americana a partir de la cual recién habremos de ganar, si cabe, nuestro verdadero lugar, y no esa penosa universalidad que todos pretendemos esgrimir inútilmente"37. Pero el estar es la base del ser, y de ahí la permanente fagocitación (el engullimiento) del segundo por el primero: "[...] la fagocitación es una ley primitiva que consiste en que sea natural que haya distensión y que la tensión, como la del ser, sea antinatural o circunstancial. El estar aquí es previo al ser alguien porque supone un estado de recolección, de crecimiento o acumulación $y$, por lo tanto, de privación y de ayuno de objetos y de elementos [...]. Por eso el estar es pasivo y femenino, como lo es toda cultura agraria o como se da en el fondo de la ciudad del siglo XX [...]. En la pasividad de ambos se da el reconocimiento de la naturaleza como ira de dios o como temor ante la tormenta, el rayo y el trueno y, en el fondo de la ciudad, el miedo terrible ante lo imprevisto. El ser, en cambio, es absoluto: tiene su propio mundo, el del mercader con su atado de géneros que invade agresivamente el mundo original del estar, como lo hizo Pizarro o lo hacen hoy los cohetes espaciales. El ser, para tener consistencia, crea cosas, como las ciudades con sus objetos y utensilios, haciéndose masculino en su actitud de agredir todo aquello que no responda a su fin. Pero como tiene que mantener una tensión ficticia se desempeña en un ámbito cerrado y obtuso, que excluye la posibilidad de la distensión [...]. Por eso mismo el ser es fagocitable, como lo es todo lo que tiende a una actitud absoluta y no tiene sus raíces en la vida. $Y$ es que el ser no puede darse sin el estar, porque en este último se da la vida en mayor proporción que en aquél. Aquél surge del estar. El estar brinda al ser los elementos para su dinámica"38. 
Esta metafísica tiene una razón gramatical en su base. En concreto, es la peculiaridad de la gramática quechua la que brinda ocasión de hacer aquella ambiciosa extrapolación metafísica. Kusch dice que la "prevención o defensa ante la ira de dios se refleja incluso en la gramática quechua. Ahí se advierte que es una cultura que tiene un sujeto inmóvil que recibe pasivamente las cualidades de su mundo. En el quechua, el verbo copulativo cay es el equivalente de los verbos castellanos ser y estar, pero con una marcada significación de estar. Cay es lo mismo que el demostrativo homónimo en quechua. Por eso, esta lengua no tiene conjugación propiamente dicha [...], sino que ésta se hace adjudicando cualidades a un sustantivo. Ésta es la clave de la mentalidad indígena [...]. No hay verbos que designen conceptos abstractos sino que sólo señalan una adjudicación pasajera de cualidades a un sujeto pasivo [...]. La cultura quechua era profundamente estática [...]. Era un estatismo que abarcaba todos los aspectos de la cultura [...], como si toda ella respondiera a un canon uniforme, que giraba en torno del estar en el sentido de un estar aquí, aferrado a la parcela cultivada, a la comunidad y a las fuerzas hostiles de la naturaleza [...]. Este mero estar encierra todo lo que el quechua había logrado como cultura. Supone un estar 'yecto' en medio de elementos cósmicos, lo que engendra una cultura estática, con una economía de amparo y agraria, con un estado fuerte y una concepción escéptica del mundo. Todo lo cual se debió dar también en los imperios anteriores. Por ese lado encontramos un término de comparación entre la cultura quechua y la occidental. Todo lo europeo es lo opuesto a lo quechua, porque es dinámico, lo cual nos aventura a calificarlo como una cultura del ser, en el sentido de ser alguien, como individuo o persona [...]. Ello se da, ante todo, en la manera de conformar la vivencia religiosa, por ejemplo. El refugio del quechua en el sasiy o ayuno frente a la fiesta del mundo indica de por sí una resistencia a éste. El sujeto, que se encuentra a sí mismo en el mandala, es un sujeto afectado por las cuatro zonas del mundo y, por lo tanto, remedia esa afectación mediante la contemplación. Es la raíz de su inacción o estatismo. La cultura occidental, en cambio, es la del sujeto que afecta al mundo y lo modifica y es la enajenación a través de la acción, en el plano de una conciencia naturalista del día y la noche, o sea que es una solución que crea hacia fuera, como pura exterioridad, como invasión del mundo, como agresión del mismo y, ante todo, como creación de un nuevo mundo. De ahí la estática de uno y la dinámica del otro" ${ }^{39}$. 
Hay dos notas a estos párrafos recién citados que conviene mencionar. Primera: "emplear el concepto de estar como cualidad de una cultura no deja de ser una herejía filosófica. No encuentro otra manera para calificar a la cultura quechua. Sin embargo, no está muy lejos esta denominación de la terminología filosófica que actualmente se utiliza. El mismo concepto de Dasein de Heidegger, que siempre es traducido como 'ser ahí', sin embargo, tiene un sentido de 'mero estar', o sea, de 'darse'”. Y segunda: mientras el sánscrito, el griego y el latín distinguen ser y estar, el francés, el inglés y el alemán no, "porque pertenecen a un ámbito que ha asimilado el estar al ser o, mejor dicho, eliminaron el estar por ser culturas esencialmente dinámicas, como lo prueba su indiscutible regencia industrial y política en este siglo XX. Son culturas del ser, inadaptables a cualquier ámbito porque crean su propio mundo" 40 .

Tenemos, entonces, dos formas distintas de religión. Kusch las llama 'fe del indio' y 'fe del cura', es decir, la fe peculiar de América y la fe típicamente europea. La fe indígena recae en "algo que está afuera y que no es el hombre, sino lo inhumano, la naturaleza o el dios terrible, como quiera llamársele [...Allí donde] se da el juego entre hombre y naturaleza en su antagonismo primitivo, en ese margen en donde fermentan las antiguas raíces de la religión y se incuba una ética, una doctrina o una teología" ${ }^{41}$. Es la fe en el dios del rayo, el relámpago y el trueno. La fe europea, por el contrario, es una fe fácil, llena de fórmulas, dicotómica y persecutoria. El del padre, en el fondo, es ese mismo dios. Pero aparentemente (he ahí una verdadera neurosis) tiene el aspecto de otro dios, un dios "de culpas y pecados originales, o sea, un dios estrictamente intelectual o, mejor, moral y, lo que era peor, se lo esgrimía como un tabú o un axioma para tapar la ira de dios, el de los relámpagos, los rayos y los truenos" " "El simple estar como despojo y desnudez no sería tolerable, si no lo sostuviese un cierto afán de lo absoluto. Éste da consistencia al estar $\mathrm{y}$ es lo que torna milagrosa la vida del indígena o la del habitante anónimo de la gran ciudad. El estar es la instalación en el hábitat real de la casa, el paisaje, el trabajo, la ciudad o lo que fuera [...]. Lo absoluto es por su parte la comprensión seminal y tensamente arqueada sobre el desgarramiento en que siempre se halla el cosmos [...]. Es la verdadera diferencia entre el indígena y el ciudadano, por cuanto aquél mantiene el afán de lo absoluto en un plano innombrable, 
mientras que éste tiende a connotarlo, y lo convierte en libro [...]. Ahí lo absoluto no se pierde, pero se subvierte" ${ }^{33}$. Es, en palabras de Kusch, el "muladar de la antigua fe", la mística, la religiosidad de la ira divina al interior de América ${ }^{44}$.

El altiplano, dice Kusch, es el espacio de lo inmenso por excelencia, de lo que suscita unas emociones originales: respeto y terror, pero a la vez fascinación y atracción. Los dioses pueden pasear por él libremente. Mientras la división ente lo hermoso y lo feo pierde vigencia, "se restablece la antigua división entre lo sagrado y lo profano" ${ }^{\text {" }}$. Lo sagrado no es sino el misterio de la manifestación libre y abierta de 'los dioses': "lo sagrado para el indio sigue siendo Dios"46. Mas, a veces se tiene la impresión de que la sacralidad no es otra cosa que una proyección humana. Los dioses son objeto de creencia, y una creencia es "la prolongación de una mismo hacia afuera". El indio altiplánico vive en el asombro, tal como los primitivos. Por lo mismo, "tiene entonces una puerta abierta por donde su vida se le escapa y se convierte afuera en dioses [...]. El indio entonces comienza su vida adentro de sí mismo, lleva a ésta hacia fuera y la convierte en dioses, y los dioses vuelven sobre él". El citadino, en cambio, vive en el espacio reducido y circunscrito de la ciudad. Gracias a él puede dividir las cosas en feas y hermosas con relativa facilidad, mientras que la contraposición fundamental entre lo sagrado y lo profano se evapora. Asimismo, en la ciudad pierden vigencia los dioses: "se diría que en la gran ciudad ponemos un pie afuera ante cada novedad, pero nunca encontramos el suelo que nos sirva de apoyo, o, mejor dicho, los dioses en quienes creer" ${ }^{47}$. Estos dioses bien pudieran constituir el término de una creencia politeísta, o panteísta o, incluso, de una suerte de monoteísmo primitivo y primordial asentado en un Dios tronante e iracundo, elemental y conciliador de los opuestos: "el espacio que vivía el quechua no estaba vacío, sino que estaba contaminado por la divinidad"48. Comoquiera que sea, el tránsito entre el hombre y la divinidad es allí fluido: "el pueblo siempre intenta hablar con Dios"49.

Estas ideas de Kusch han tenido repercusión en otros autores argentinos. Es el caso de Scannone y de Cullen. Para el primero, por ejemplo, el estar es una dimensión metafísica fundamental y su raíz religiosa es indiscutible. El estar es una "dimensión previa, numinosa e indisponible". Es "lo Sagrado, que es indisponible y abisal". Es "dimensión religante irreductible" 50 . Como se ve, el estar en Kusch tiene

\section{9}


un carácter a la vez religioso y simbólico. El mismo Ellacuría (Scannone no indica la procedencia de la cita) habría visto un paralelismo entre el estar en Kusch y la realidad en Zubiri ${ }^{51}$. Cullen también ha acogido la categoría del estar: “el hombre, en el 'estar', 'chapotea' lo absoluto, en la feliz expresión de R. Kusch. Participa y entiende sapiencialmente lo absoluto: pero no es absoluto. Lo absoluto, para el hombre, es siempre una presencia-ausencia, o una dación-sustracción" ${ }^{52}$.

Con este panorama, podemos tematizar brevemente el estatuto y el método del pensamiento de Kusch. Se trata, a no dudarlo, de una combinación de antropología y filosofía ${ }^{53}$. Serán los antropólogos quienes tendrán que decidir acerca de la rigurosidad y la relevancia de esta antropología del fondo popular e indígena que definiría a la América Latina. Es éste, pues, un problema científico que ha de resolverse apelando a la experiencia. Pero, además, no puedo dejar de advertir que en Kusch abundan las afirmaciones excéntricas, por decir lo menos. Su defensa de la peculiaridad metafísica y religiosa de América a veces lo lleva a proclamas mesiánicas: "quizá sea nuestro destino volver a ser aquí hombres sin sucedáneos, porque ése es el destino de América: la comunidad y la reintegración de la especie" ${ }^{24}$. En otras ocasiones ese mesianismo americanista se transforma punto menos que en desprecio por la ciencia europea: "la realidad es un animal monstruoso, en donde todo lo que ocurre sigue las leyes de la vida: nace, madura y muere. Por eso Newton fue un mentiroso. Vio caer una manzana y creyó descubrir las leyes de la gravedad. Mintió porque dijo que la realidad no es un animal sino un mecanismo. Pero en América sabemos que él no tuvo razón" ${ }^{\text {"S }}$. Tampoco faltan confesiones acerca del sustrato hondamente popular, casi se diría subterráneo, del peronismo: "la arqueología y la etnología convierten al indio en una cosa mensurable que situamos en el patio aquel de los objetos. ¿No ocurre lo mismo cuando se habla de 'peronismo'? Se lo rechaza objetivamente sin saber que esencialmente forma parte de nuestra subjetividad". Eva Perón habría captado el así de la realidad y por eso el pueblo la quiso canonizar ${ }^{56}$.

Pero más allá de eso, ¿hay aquí una filosofía de la religión valiosa, original y rigurosa? Me parece que no. En los textos de Kusch hay ostensiblemente vacilaciones de gran envergadura. Ya lo hemos vislumbrado a propósito de la idea de religión de este autor. A veces, parece tratarse de la religión entendida como pura proyección huma- 
na. Otras veces, parece ser algo más: la religión como una suerte de panteísmo o politeísmo primordiales. También podría tratarse de un cristianismo primitivo progresivamente periclitado en Europa. Tampoco puede descartarse que la religión sea en el fondo el campo variable de las hierofanías, concebible incluso en ausencia de divinidades: sería algo así como una actitud temblorosa, pasiva ante el misterio tremendo y fascinante de la vida. Lo grave es que en los textos de Kusch no se encuentran razones decisivas para inclinarse a favor de una u otra de estas alternativas. $Y$ sin una idea precisa de religión, como es obvio, no es siquiera imaginable alguna filosofía de la religión. Esta imprecisión de la idea de religión está asociada a otra imprecisión, sobre la cual reposa la entera obra de Kusch: la distinción entre ser y estar como distinción metafísica entre dos.culturas, la europea y la americana. Por supuesto que se puede diștinguir metafísicamente entre ser y estar, tal como puede y debe distinguirse entre la cultura de Europa y la de América. No faltaba más. El problema es éste: ¿puede ligarse una distinción con la otra? Esto es, la cuestión es si puede otorgarse sensatamente rango no sólo antropológico y social sino además estrictamente metafísico a la diferencia entre el modo de ser europeo y americano. A mi modo de ver, esta tendencia ontologizante para la cual la idea de América equivaldría a un ê̂dos paradigmático, a una cuestión que toca — digámoslo así- a los fundamentos primarios en el orden del ser y del conocer, yerra completamente el camino. No se puede transformar tan alegremente y sin solución de continuidad un asunto cultural e histórico en una disputa metafísica. Por esto es por lo que la suya termina siendo una filosofía folklórica, en el mal sentido de la expresión.

Pero hay más. Al lado de estas vacilaciones fundamentales pueden mencionarse otras tantas. Así, de cuando en cuando aparecen claros alegatos en favor de la cultura europea y occidental. Parece necesaria una sólida formación filosófica y un conocimiento riguroso del fenómeno religioso para estudiar las cosmovisiones indígenas. Dice Kusch, por ejemplo, que para encontrarse con la auténtica actitud espiritual de los antiguos peruanos "se necesita tener ante todo una cultura filosófica y conocer algo más sobre religión [que lo que demuestra conocer Ricardo Latcham]. Con las solas ideas sobre tótem y tabú y la actitud meramente arqueológica no se puede hablar de religión precolombina" ${ }^{57}$. Para qué hablar de la influencia en Kusch de Heidegger,

\section{1}

Sobre la filosofía de la religión en América Latina 
sobretodo de sus ideas acerca del mundo moderno y de la técnica, las cuales están intensamente presentes a lo largo de toda esta obra, como hemos visto. En alguna ocasión, incluso, se tiene la impresión de que Kusch adopta una perspectiva evolucionista que permitiría distinguir entre diversos grados de desarrollo cultural. Así, cuando se refiere a la "incorporación del dios, sea como teofagia, sea simplemente como incorporación mística del mismo", añade que "estas dos formas corresponden a dos escalones de distinta evolución cultural [...]." ${ }^{.58}$. Mas, por otra parte en Kusch predomina indiscutiblemente la relativización de la idea de progreso en general y de la filosofía occidental en particular, en beneficio de una aproximación antiintelectualista que sería más apta para entender lo americano. Ya lo hemos visto sobradamente. De hecho, hay similitudes entre las categorías de los pueblos protohistóricos y nuestro propio inconsciente ${ }^{59}$. El caso de Jung ilustra esta tensión entre la apropiación de ideas europeas y el rechazo tajante de las mismas. Jung es citado profusamente ${ }^{60}$. Y, sin embargo, Kusch dice que Jung "esgrime los arquetipos sólo para revitalizar una burguesía europea agotada" y termina por "ser juego de gabinete", tal como le ocurre también al estructuralismo de Lévi-Strauss. Ninguno de los dos es totalmente convincente; "sólo son útiles recién cuando la observación justifica la utilización de los mismos"

Por eso, pienso que en Kusch nos podríamos encontrar, en el mejor de los casos, con una posibilidad. Es la posibilidad de una reivindicación honesta de lo que se ha dado en llamar 'indigenismo' y 'negritud', de esa efectiva dimensión latinoamericana que no es reductible a fuente europea alguna y que - todo lo mestizada que se quiera- nos distingue y especifica. A mi modo de ver, una buena comprensión de esta dimensión es la que ofrecía Zea al citar las expresiones de un defensor afroamericano de la idea de negritud, Aimé Césaire: "afirmábamos [...] que el negro era un hombre como otro y que había realizado cosas dignas de ser consideradas dentro del marco de la creación universal a las que queríamos ser fieles' [...]. Negritud e indigenismo tienen así una preocupación común, el mestizaje cultural a partir de la situación concreta del hombre que sostiene la una y el otro, la dependencia [...] Asimilar, sin ser asimilado [...]. No se trata de negar el ser negro, o el ser indio o latinoamericano para poder ser europeo u occidental; sino de ser también europeo u occidental sin dejar por ello de ser negro, indio o latinoamericano. No se trata de

\section{2}

Realidad 103, 2005 
repetir, imitando, sino de asimilar, recrear, imaginar e inventar [...]. 'Imitar, decía el mexicano Antonio Caso, si no se puede otra cosa; pero aun al imitar, inventar un tanto, adoptar, dirigir la realidad, partir de ella" ${ }^{22}$.

Pero tiendo a pensar que, de acuerdo a la línea dominante en sus escritos, Kusch puede ser hecho reo de una versión indefendible del indigenismo y la negritud. Ya lo he insinuado. Una preciosa caracterización de ella la hallo en la última novela de John M. Coetzee, Elizabeth Costello. Ésta es una espléndida ficción acerca de las ideas de una conocida escritora australiana ya mayor. Pues bien: en uno de los capítulos de esta novela, la protagonista hace un crucero gratuito desde Christchurch hasta Ciudad del Cabo en el buque Northern Lights, con la única obligación de dar una conferencia a los demás pasajeros del barco. En dicho crucero Elizabeth Costello se reecuentra con un viejo conocido, Emmanuel Egudu, escritor nigeriano que también viaja gratuitamente con la carga de disertar, en su caso sobre 'La novela en África'. Cito: "la négritude: Elizabeth pensaba que Emmanuel dejaría atrás esa pseudofilosofía con la edad. Es evidente que no. Es evidente que ha decidido conservarla como parte de su discurso profesional" [... E. C.:] ¿Por qué hay tantos novelistas africanos y todavía no hay ninguna novela africana que valga la pena mencionar? Ésa parece ser la verdadera pregunta. Y tú mismo has dado una pista para responderla en tu charla. El exotismo. El exotismo y sus seducciones [...]. La novela inglesa — dice Elizabeth- la escribe básicamente gente inglesa para otra gente inglesa. Por eso es la novela inglesa. La novela rusa la escriben rusos para otros rusos. Pero la novela africana no la escriben unos africanos para otros africanos. Puede que los novelistas africanos escriban sobre África y sobre experiencias africanas, pero a mí me parece que todo el tiempo que escriben están mirando por encima del hombro hacia los extranjeros que los van a leer. Les guste o no, han aceptado el rol de intérpretes e interpretan África para sus lectores. Pero ¿cómo se puede explorar un mundo con plena profundidad si al mismo tiempo se lo tienes que explicar a unos forasteros? Es como si un científico intentara prestar una atención plena y creativa a sus investigaciones y al mismo tiempo tuviera que explicar lo que está haciendo a una clase de alumnos ignorantes. Es demasiado para una sola persona, no se puede hacer, al menos no en profundidad. Ahí me parece que está la raíz de vuestro problema. 
Tener que representar vuestra africanidad al mismo tiempo que escribís [...]. En opinión de Elizabeth, todo lo que dice Emmanuel sobre la novela oral, una novela que se ha mantenido en contacto con la voz humana y por tanto con el cuerpo humano, una novela que no es incorpórea como la novela occidental sino que es portavoz del cuerpo y de la verdad del cuerpo, no es más que otra forma de sustentar la mística de los africanos como últimos transmisores de las energías humanas primordiales. Emmanuel culpa a sus editores occidentales y a sus lectores occidentales de convertir África en algo exótico. Pero a Emmanuel le interesa convertirse en algo exótico"63. Análogamente, creo que Kusch cae en la tentación del exotismo. Y que lo hace tan violentamente que llega a poner en peligro la posibilidad misma del diálogo. La de Kusch, decía, termina siendo una filosofía folklórica. Éste es el riesgo de ciertas posiciones contextualistas o comunitaristas muy extremas: la partición a radice de la razón y de la convivencia es inseparable de la puesta en cuestión de ese plano común a todos, sin el cual es simplemente imposible reconocernos y dialogar.

3. Otra manera de desarrollar una filosofía de la liberación de corte ético-cultural es la de Juan Carlos Scannone. Es un autor menos radical y más abierto a la filosofía europea, pero que de todos modos sigue parcialmente la ruta de Kusch, sin dejar de mostrar una simpatía crítica por el proyecto de Dussel. Scannone emplea la expresión 'filosofía de la religión' tal como lo hace W. Weischedele ${ }^{64}$, es decir, como “teología filosófica' o lógos (filosófico) acerca del theós”. Este theós es el Dios vivo del que habla Pascal, el misterio sagrado tremendo y fascinante, el Dios de la religión, la praxis y la historia que se des-vela libre y gratuitamente y se re-vela ética y absolutamente ${ }^{65}$. Debe tenerse cuidado de no confundir el lógos acerca del theós - la filosofía de la religión- con la teología revelada: "tengamos en cuenta que lo que el creyente interpreta como experiencia y lenguaje de fe, el filósofo de la religión puede interpretarlo en otro nivel hermenéutico, como experiencia y lenguaje religiosos histórica y socioculturalmente condicionados, que el filósofo aborda con su propio método"66. La filosofía de la religión, por lo tanto, es un lógos teóricamente autónomo, pero a la vez es un "lógos del símbolo (al que interpreta en concepto) y lógos de la libertad (a la que condiciona a la par que es condicionado por ésta), sin reducirse a ello" ${ }^{\prime 6}$. 
Scannone intenta rescatar de modo crítico la tradición de la filosofía europea. Así es como pasa revista al lenguaje premoderno de la transcendencia (san Anselmo y santo Tomás), a la crítica moderna de aquel lenguaje (Descartes, Leibniz, Kant, Hegel, Feuerbach, Marx, Nietzsche y Freud) y a la superación posmoderna de la metafísica de la subjetividad (Heidegger, Blondel y Lévinas) ${ }^{68}$. El objetivo de Scannone es el de replantear las ganancias de la filosofía europea desde la situación latinoamericana, esto es, desde una universalidad situada "en el ahora y aquí de América Latina"69. Ésta, a sus ojos, es una situación de subdesarrollo y dependencia, de conciencia y ruptura de ella a través de una praxis de liberación y, por fin, de una nueva experiencia y un nuevo lenguaje religiosos ${ }^{70}$. En cuanto a esto último, Scannone asegura que "en América Latina ha surgido, o mejor, está surgiendo un nuevo lenguaje de la transcendencia, que intenta expresar una experiencia religiosa históricamente nueva, experiencia que se media y está mediada por la praxis de liberación latinoamericana. De ahí que se trate de un lenguaje religioso de liberación [...]. Se trata por tanto de ir articulando reflexivamente el momento de sentido propio de la nueva experiencia religiosa latinoamericana, es decir, de la experiencia religiosa que se da cuando desde la apertura a la transcendencia se asume práctica y críticamente la transformación del mundo en una situación de dependencia"71.

Scannone puede decir que en América Latina se verifica una tensión fecunda entre praxis e historia de liberación, por una parte, y apertura a la novedad de la transcendencia, por la otra. Precisemos el sentido de estas afirmaciones. Primeramente, en cuanto al punto de partida del nuevo lenguaje de la transcendencia, Scannone quiere despejar algún equívoco y subrayar la inconclusión, la apertura de la historia y la praxis: “[...] podría creerse que el punto de partida del nuevo lenguaje de la transcendencia se deriva en circularidad dialéctica de la praxis histórica de liberación. Pero si solamente fuera así, no se ve por qué se trataría de un lenguaje de la transcendencia, y no sólo del de una mera inmanencia histórica, como sucede en el marxismo. Hay que radicalizar el planteamiento. Pues la praxis de liberación según nosotros la interpretamos [...] - ya es respuesta libre a una palabra cuestionante que convoca. ¿Desde dónde surgen esa interpelación y ese llamado? [...] Surgen desde los pobres [...]. El punto de partida del que habláramos, aunque éticamente absoluto, no es un

Sobre la filosoría de la religión en América Latina 
'punto de partida' como el que buscaba la modernidad de Descartes a Husserl, un punto de partida sin presupuestos. Al contrario, nace de la abisalidad de la historia y de la praxis, como lo sugeríamos siguiendo respectivamente a Heidegger y a Blondel, pero con una muy concreta determinación histórica y práctico-política, que determina el lenguaje de transcendencia que de ahí nace, sin hacerle perder su apertura y transcendencia. Pues esa determinación no es reductible a una dialéctica, como en Hegel y Marx. Y por ello está abierta a lo imprevisible histórico y a la novedad original de nuestra historia propia. Historia y originalidad de un pueblo no son deducibles, ni siquiera dialécticamente, de ninguna ciencia universal o de leyes objetivas, como tampoco lo es la transcendencia"72. A la experiencia religiosa pertenecen, pues, una genuina alteridad y una genuina transcendencia, "la alteridad absoluta del transcendente" ${ }^{\text {"73 }}$. Pero en América Latina estas dimensiones religiosas están mediadas social y estructuralmente, de modo tal que la pregunta por el sentido supone la experiencia real y política de la negación del sentido "en la práctica de la violencia y la injusticia". Por esto es por lo que ésta no sería una prueba puramente teórica de la existencia de Dios, sino su probación itinerante y escatológica - 'ya, pero todavía no'-, una veri-ficación vital y activa que es luego reflexivamente articulada ${ }^{74}$.

En segundo lugar, Scannone habla de la necesidad de una ruptura epistemológica y de una verdadera con-versión al pueblo. El lenguaje filosófico de la transcendencia libera al lenguaje científico y político de su univocidad, de su rigidez, de su absolutización ideológica, sin perder en determinación histórica y fuerza práctica ${ }^{75}$. A la vez, esa "ruptura del lenguaje secular" lleva a la ruptura correspondiente del lenguaje religioso en lo que puede tener de "seudotranscendencia ahistórica y cerrada ideológicamente", de evasión transmundanal ${ }^{76}$. Además, esta ruptura implica una apertura al pueblo latinoamericano, a la mediación histórica, práctica y lingüística de la sabiduría popular, a la novedad de la cultura popular mestiza y de su lógos, de sus símbolos, mitos, ritos y fiestas. De ahí la necesidad de practicar una 'vía larga', es decir, una hermenéutica de los símbolos populares latinoamericanos, religiosos y profanos ${ }^{77}$. En particular, es decisivo salvar unas dimensiones no modernas que fueron estigmatizadas como 'barbarie' por la 'civilización' ilustrada: “dimensiones de apertura a la transcendencia que la razón ilustrada tendía a desconocer, a saber, 
dimensiones de gratuidad (que fueron consideradas como ineficacia o pereza), dimensiones de misticidad y afectividad profundas (que se miraron como irracionales), dimensiones explícitamente religiosas (que se despreciaron como superstición)" "78. Scannone valora de tal manera el lógos de la sabiduría popular que dice que "es un lógos libre, pero religado; universal, pero situado. Su reserva de sentido y su pertenencia raigal lo abren siempre a nuevas situaciones históricas y geo-culturales, y a nuevas manifestaciones de lo Sagrado que, sin embargo, se sustrae" 79 . Este autor asegura que la religión y el lenguaje tienen por lugar originario a la sabiduría popular: ésta es "mediación originaria entre la religión -cuyo momento lógico atemático (cuya sapiencialidad) se dice en lenguaje-y el lenguaje, que -comprendido en su nivel antropológico y cultural - surge de un núcleo originario atemático y supracategorial (sapiencial) de sentido último, al que le es inherente la instancia religiosa" $"$.

Scannone, por último, propone marchar a partir de la mediación simbólica hacia un nuevo lenguaje analógico, una auténtica analogia symboli ${ }^{81}$. La analogía no es sólo un procedimiento lógico, sino - como decía Przywara- una "estructura primordial", un "ritmo, proceso o movimiento" que no tiene carácter dialéctico, que es más bien 'ana-léctico'82. Pero nuevamente se relee aquí la tradición europea: la analogía ha de pasar por la crítica moderna y posmoderna y debe ser sometida, además, a una crítica histórica, ética y política ${ }^{83}$. Se trata de "un lógos distinto del de la modernidad", que rescata "la dimensión del símbolo, aunque comprendiéndolo como determinadamente histórico y eficazmente práctico. Sólo un tal lenguaje será capaz de articular reflexivamente la esperanza y las aspiraciones del pueblo latinoamericano — su utopía-, así como la fe que el mismo pueblo tiene en su liberación, o la mística que lo anima" ${ }^{84}$. Notemos que Scannone, de la mano del símbolo, sitúa lo específica e irreductiblemente religioso en lo sagrado y divino, en el ámbito del Absoluto que se manifiesta y se sustrae: "pues lo Santo, en el símbolo, se epifaniza para nosotros, aunque como misterio santo; y se nos $d a$ y comunica graciosamente, aunque en forma absolutamente indisponible y adorable" 85 . Así, Scannone dice que para pensar conceptualmente el símbolo religioso debe evitarse la tentación de manipular o limitar el exceso de sentido que caracteriza a las hierofanías y teofanías. El símbolo 'da que pensar' — como dice Ricoeur- a tra- 
vés de la transmisión de un 'sentido de sentido', es decir, de un segundo sentido transcendental que tiene lugar en un sentido primero, a través de él y a la vez apuntando más allá de él. Por lo mismo, no hay mejor manera de tratar conceptualmente al símbolo que haciendo uso de un procedimiento analógico, gracias al cual el sentido religioso es ciertamente afirmado, pero no reducido por agotamiento a puro concepto: "el movimiento especulativo propio de la analogía implica una primera afirmación de un sentido positivo, en y a través del cual, pasando por la mediación de la negación, se llega a una segunda afirmación de eminencia" ${ }^{\prime 6}$. Ninguna idea religiosa puede expresar de manera exhaustiva (unívoca o dialécticamente) al misterio sagrado y divino como misterio sagrado y divino. Dicha pretensión - Scannone cita a Marion- sería siempre y sólo una transformación del ícono en ídolo. El concepto religioso, aunque no es equívoco, es constitutivamente inadecuado. Olvidarlo sería una violación de la libertad característica y constitutiva del campo religioso. De ahí que la analogía esté signada "por la libertad, tanto por la libertad indisponible de la transcendencia como por la del pensar humano liberado que la acoge especulativamente, libertad no sólo personal sino comunitaria" ${ }^{37}$.

Para ser franco, Scannone me parece un caso de extraordinario eclecticismo, mayor aún que el de Dussel. Sus ensayos de filosofía de la religión son por sobretodo una reunión caleidoscópica de autores: Blondel, Heidegger y Lévinas, algo de marxismo, de Dussel y de Kusch, santo Tomás y Ricoeur, la perspectiva del pobre, de la sabiduría popular y de la teología de la liberación. Scannone repite una y otra vez esta acumulación impresionista de múltiples perspectivas, motivo por el cual el resultado final de sus esfuerzos carece -a mi manera de ver- de sistematicidad y perfil propio. No se encuentra en este autor una síntesis capaz de ser reconocida y discernida públicamente. Casi me atrevería a afirmar que es preferible acudir directamente a las numerosas fuentes de las que se sirve Scannone, antes que a él mismo. No se trata de discutir el valor de hacer acopio de diversas fuentes filosóficas. Por ejemplo, la idea de símbolo de Ricoeur muestra aquí su productividad: Scannone acierta cuando sostiene que la noción de analogía puede emplearse de una manera filosófica y, por ende, universalizable. Y también acierta cuando corrige la cerrazón dialéctica del pensamiento marxista en beneficio de la novedad de la historia y de la apertura del hombre a la transcendencia sagrada y a la posibili- 
dad de Dios. Pero no todas las influencias son tan felices: Scannone acoge la muy discutible noción de estar de Kusch. En fin. Lo que aquí interesa destacar es que de la mera reunión de autores e ideas no resulta más que un material para hacer filosofía con originalidad. Ésta supone la adopción de un punto de vista que ponga en una nueva perspectiva a esa diversidad de influencias intelectuales. Y esto es justamente lo que se echa de menos en Scannone. Por lo demás, como en Dussel y en Kusch, aquí tampoco se combinan coherentemente algunas de las distintas direcciones teóricas puestas en juego: por ejemplo, como ya hemos dicho, no parece consistente defender a la vez la inmediatez ética en la que tanto insiste Lévinas - fenomenología pura y dura - y la vía larga de las mediaciones simbólicas defendida por Ricoeur -hermenéutica que desconfía de la pretensión fenomenológica de primariedad.

Además, pienso que Scannone toma ciertas opciones particulares que deben ser discutidas. Este autor abusa de la idea de sabiduría popular. Parece como si la filosofía de la religión en América Latina debiese tener por fundamento y límite aquello que el pueblo hace, piensa y siente. Ciertamente que se puede aprender de las ideas, metáforas y fiestas populares. Pero no debe olvidarse que la filosofía es -en expresión de Hegel_ 'el mundo al revés' (die verkebrte Welt). Y esto también vale para la sabiduría popular. Por muy distinta que ella sea en comparación con las ideas socialmente dominantes, la filosofía no puede detener su faena crítica ante ningún saber constituido. La filosofía tiene una dirección distinta de aquella que siguen la reflexión cotidiana y la empresa científica. Su quehacer es tan radicalmente crítico que no sólo no debe dejar nada sin cuestionar, sino que ha de redoblar sus esfuerzos ante todo aquello que esté revestido de autoridad, sea ésta de dominio o de resistencia. Por lo demás, no se ve por qué razón la única o principal fuente de una filosofía latinoamericana de la religión habría de ser la sabiduría popular. Salvo que se reconocieran en ella ciertos privilegios que ya suponen una determinada opción religiosa del filósofo. Mas, como hemos visto, esto no es legítimo en una filosofía de la religión. Sí lo es en una investigación teológica. Ésta puede admitir ciertas ventajas en la situación y la perspectiva de los pobres, perseguidos y pecadores. Pero Scannone, aunque en principio distingue, no siempre mantiene la diferencia entre la perspectiva filosófica y la teológica. Por ejemplo, habla con frecuen-

\section{9}

Sobre la filosofía de la religión en América Latina 
cia de un Dios liberador que opera en la historia aunque se manticne transcendente e inmanejable: ¿es ésta una imagen de la divinidad que puedan compartir todas las religiones? ¿No es más bien una idea monoteísta y profética de Dios? En un sentido semejante, Scannone afirma que habría 'un nuevo lenguaje de la transcendencia' en América Latina, 'un lenguaje religioso de liberación'. ¿Podría entonces decirse -en coherencia con el énfasis que pone Scannone en la cultura popular - que el afán de una filosofía de la religión en América Latina ha de conducir a unos contenidos esencialmente peculiares y divergentes de los de las filosofías desarrolladas en otras latitudes? Admitamos que la cuestión no es clara en este autor. Pero advirtamos también que si se prosiguiese por esta línea posible arribaríamos a posiciones semejantes a las que defiende Kusch. En tal caso, ya hemos afirmado la necesidad de poner en tela de juicio a esas comprensiones exorbitantes de la peculiaridad latinoamericana. $Y$ es que la filosofía es un quehacer intelectual que no puede prescindir de unas condiciones mínimas de publicidad y universalidad, por más que atienda a su situación de origen y respete la constitutiva inadecuación de sus argumentos.

\section{2. ¿Filosofía fenomenológica de la religión en América Latina?}

Los morosos exámenes anteriores nos sitúan ante el siguiente problema: ¿cómo puede elaborarse en América Latina una filosofía de la religión consistente y rigurosa? ¿Podemos reconocer de hecho una filosofía de la religión que supere las deficiencias de proyectos como los de Dussel, Kusch y Scannone? Mi hipótesis es que ya existe entre nosotros una cierta escuela que bien pudiera superar las carencias de los ensayos anteriores. A no dudarlo, dicha filosofía de la religión tendrá que partir por ocuparse con el problema de su propio punto de partida. Para ello no deberá aceptar presupuesto alguno sin antes someterlo a crítica. Por fin, tendrá que ser capaz de integrar las diversas posibilidades contemporáneas de estudio de los fenómenos religiosos. Me refiero, más precisamente, a la filosofía de la religión que, partiendo de la obra de Zubiri, ha encontrado no sólo eco sino precisa articulación en Ellacuría y González. En esta tríada se halla la realidad y la posibilidad de una filosofía fenomenológica de la religión. Veámoslo. 
1. Digamos desde ya que la fenomenología ha dejado una huella profunda en América Latina. Considerada en sentido amplio, es ese movimiento filosófico fundado por Husserl y proseguido - con mayor o menor fidelidad al fundador- por una vasta serie de filósofos: desde Ortega, Scheler y Heidegger, Lévinas y Merleau-Ponty, hasta Gadamer y Ricoeur, Henry, Derrida y Marion. Así considerada, es evidente la influencia de este movimiento en la filosofía latinoamericana. $\mathrm{Y}$, sin embargo, que yo sepa, no abundan los estudios sobre el impacto de la fenomenología en América Latina. En muchos casos, creo, esto se debe a un par de razones: primero, a una caracterización excesivamente estrecha de la fenomenología, según la cual ésta no es más que la obra de Husserl (o determinados aspectos de la obra de Husserl), y segundo, al desconocimiento de las deudas específicamente fenomenológicas contraídas por muchos autores latinoamericanos, tanto dentro como fuera de la filosofía de la liberación.

A propósito del deficitario tratamiento histórico que ha recibido la fenomenología en América Latina, me contentaré con sólo un ejemplo: la reciente Historia del pensamiento filosófico latinoamericano de Carlos Beorlegui. Pese a sus muchos méritos, esta extensa obra otorga una reducida presencia a la fenomenología. Rara vez se la menciona directa y autónomamente ${ }^{88}$. Claro que se habla de ella indirectamente, a través de pensadores europeos e hispanos importantes para el desarrollo de la fenomenología en América Latina. Beorlegui sí se detiene en la influencia de autores como Ortega, Zubiri, Heidegger, Lévinas y Ricoeur en la filosofía de la liberación. Mas, de todas maneras dicha alusión por repercusión deja mucho que desear. En Ortega, salvo alguna alusión genérica a pensadores alemanes de orientación fenomenológica que lo influyeron, Beorlegui destaca sus ideas de circunstancia, perspectiva, generación, sociedad y raciovitalismo, pero sin encuadrarlas debidamente en el marco fenomenológico que les es propio $^{89}$. Respecto de Gaos, rara vez se mencionan sus reflexiones, estudios y traducciones de carácter fenomenológico ${ }^{90}$. En cuanto a García Bacca, Beorlegui comenta de paso sus etapas orteguiana y heideggeriana91. Cuando se habla de la filosofía de Ellacuría, Zubiri no es situado claramente dentro de la fenomenología ${ }^{92}$. Nada se dice de la filosofía propia de Antonio González, que es un radical ensayo de fenomenología ${ }^{93}$. Tampoco hay demasiadas pistas en este libro res- 
pecto de posibles contribuciones fenomenológicas a la filosofía de la religión en Latinoamérica.

Pero ya se dejan ver aires de cambio. He insinuado que la fenomenología ha tenido un impacto masivo en América Latina. Y esto desde hace varias décadas. Gaos en México, Cruz Vélez en Colombia, Rosales en Venezuela, Rivera en Chile, etc. son sólo algunos autores que han fungido de propulsores de la fenomenología ${ }^{94}$. Por otra parte, está cada vez más difundida la interpretación fenomenológica del pensamiento de Ortega y Zubiri. No debe pasarse por alto que ambos, los dos mayores filósofos españoles del siglo $\mathrm{XX}$, han tenido y siguen teniendo una enorme repercusión en América Latina. Últimamente se ha constituido un 'Círculo latinoamericano de fenomenología', gracias al cual se han desarrollado ya tres congresos dedicados al estudio de esta corriente filosófica (en 1999, 2002 y 2004).

2. Pero lo que aquí indagamos es el desarrollo de una fenomenología de la religión en América Latina. He dicho que, a mi modo de ver, la línea de desarrollo más interesante para la fenomenología de la religión en América Latina es la que va de Zubiri, pasa por Ellacuría, su más estrecho colaborador, y llega hasta González, destacado discípulo de Ellacuría. Ciertamente esta línea no es la única. Pueden advertirse otras líneas de desarrollo de la fenomenología de la religión, tanto en España como en América Latina. Sea de ello lo que fuere, a partir de Zubiri nos encontramos con una nueva forma de fenomenología de la religión. No me interesa exponer en detalle la filosofía de la religión que Zubiri ha llevado a cabo, ni su prolongación por parte de Ellacuría y González. Sólo quiero aludir brevemente a las ventajas de esta fenomenología de la religión, especialmente cuando se la compara con los ensayos emprendidos por la filosofía de la liberación que acabamos de revisar.

Como se sabe, la filosofía de la religión de Xavier Zubiri se despliega en tres momentos: religación, religión, cristianismo. He aquí las tres partes del problema teologal del hombre. La realidad, según Zubiri, es un modo de dársenos las cosas en nuestra aprehensión, una aprehensión que es unidad estructural de sentir e intelección, es decir, inteligencia sentiente. Concretamente, las cosas son reales en tanto en cuanto son aprehendidas como siendo 'otras', 'en propio' o 'de 
suyo' en ese mismo acto de aprehensión (y no fuera de dicho acto). Realidad no es el modo de ser de lo que es independiente de nosotros mismos, que eso sería el más ingenuo de los realismos, sino esa formalidad según la cual las cosas se presentan en nuestra intelección sentiente con alteridad. Así entendida, la realidad pertenece a cada cosa, por humilde que ésta sea. Pero le pertenece de tal modo que excede aquello que cada cosa determinadamente es. Por esto es por lo que la realidad es inespecífica, abierta, transcendental. Podemos, pues, constatar que la realidad es más que cada una de las cosas y más que nosotros mismos. Por ser más, la realidad es dominante y ejerce un poder sutil e inexorable sobre nuestras vidas. La religación es justamente este hecho radicalísimo y total: estamos atados a este poder. Es lo que Zubiri llama el poder de la realidad. La realidad es poderosa y despliega su primacía en cada acto de nuestra existencia. Lo despliega como apoyo último, como fuente absoluta de posibilidades y como lanzamiento radical que nos impele a realizarnos de alguna manera. Por esta precisa razón, dice Zubiri, los seres humanos somos absolutos, pero lo somos relativamente. Por una parte somos seres abiertos a la realidad y estamos enfrentados a ella en total, pero por la otra esa apertura y ese enfrentamiento con la totalidad de lo real son cobrados y no originarios. El problema fundamental del ser humano consiste, entonces, en cómo hará su vida en la realidad ${ }^{95}$. La religión, luego, es una plasmación posible de la religación. Pero también el ateísmo y la agnosis son posibles plasmaciones de la misma religación. Ésta es una afirmación constante de Zubiri: el teísta, el ateo y el agnóstico están en un plano de perfecta igualdad. Ninguno puede reclamar una situación de privilegio frente a los demás ${ }^{96}$. Ahora bien, las religiones son cuerpos sociales radicalmente históricos y desconcertantemente variables $^{97}$. Y el cristianismo, por fin, es para Zubiri no sólo una de las vías del monoteísmo, sino sobretodo -en sus palabras - la 'divinización de la vía de la transcendencia’ o, lo que es igual, la religión de deificación o deiformación ${ }^{98}$. Por esta inaudita peculiaridad, el cristianismo es la religión verdadera y las demás religiones no serían sino cristianismo 'de-forme', 'ab-errante', de acuerdo a las provocativas fórmulas del propio Zubiri”9.

La filosofía de la religión de Ignacio Ellacuría desborda los marcos puramente fenomenológicos. Aquí también se recurre a la religación ${ }^{100}$. Pero se apela a ella dentro de un esquema filosófico que, por decir lo 
menos, es parcialmente metafísico. Recordemos que Ellacuría -bajo la influencia de Hegel, Marx y particularmente Zubiri, sobre todo, de su curso sobre la Estructura dinámica de la realidad- llegó a desarrollar una filosofía de la realidad histórica, en el entendido de que dicha realidad histórica sería la mayor y mejor manifestación de la realidad $^{101}$. La religación de la que habla Ellacuría, ¿es el análisis de un hecho constatable para cualquiera, como en Zubiri? ¿O es ahora una teoría inscrita dentro de una metafísica intramundana? Como quiera que sea, Ellacuría subraya enérgicamente la posibilidad de la aparición de Dios - lo divino- dentro de la realidad histórica, como es tan visible en las grandes religiones. Notemos que Ellacuría habla aquí de Dios, y no del poder de la realidad. Notemos también que Ellacuría insinúa que la posible aparición de Dios se funda en que la realidad histórica es abierta. Es la transcendencia real del fundamento 'en' la historia, y no su separación de la misma. Y, tercero, advirtamos que, de haber Dios, será un fundamento inobjetivable del cual no puede tenerse otra experiencia que la práctica: Ellacuría asume aquí el núcleo de la argumentación kantiana ${ }^{102}$. No entraré aquí en los énfasis puestos por Ellacuría al tratar del cristianismo. Sólo recordemos que Ellacuría insistió siempre en una intelección radicalmente histórica -y, por lo mismo, abierta a la novedad y a la transcendencia- del cristianismo. De ahí su tesis de que el cristianismo es la historia de una salvación que transcurre escatológicamente en la historia: "no es sólo que la historia de la salvación traiga consigo una salvación en la historia; es, además, que la salvación del hombre en la historia es la única forma de que culmine la historia de la salvación"103.

Antonio González divide también en tres partes su filosofía de la religión, siguiendo el esquema básico de Zubiri y a la vez releyéndolo desde un punto de vista práctico. En el nivel más básico (el de las acciones) nos topamos con una paradoja. La alteridad de las cosas es lo más otro que nosotros mismos y es, a la vez, lo que distiende nuestra praxis y nos 'personaliza'. Esta paradoja de la alteridad, pues, nos domina con poder $y$, por tanto, nos religa. En el nivel de las acciones intencionalmente orientadas (el de las actuaciones) surgen sentidos religiosos y no religiosos. La religión, en consecuencia, consiste en el otorgamiento de un posible sentido intencional al poder de la alteridad que nos religa ${ }^{104}$. Los sentidos religiosos son numerosos y cambiantes, pues no son más que plasmaciones de la universal para- 
doja de la alteridad. En el nivel de la búsqueda transcendente (el de las actividades), la razón - provisional y corregible - se caracteriza por preguntar por el fundamento de la paradoja de la alteridad, y conduce, más allá de la alteridad radical (actualizada en nuestros actos) y de la alteridad real (que es ya independiente de los mismos), hacia una alteridad completa y total, hacia lo totalmente otro ${ }^{105}$. El cristianismo, finalmente, es para González la plena y definitiva superación por Gracia del esquema de la ley. Este autor confiesa haber vivido una crisis teológica de la cual ha resultado una radical reformulación de la teología cristiana. Si la clásica teología de la liberación —como él afirma- "no prestó suficiente atención a las estructuras últimas del pecado, y por eso mismo tampoco pudo responder con radicalidad a las formas sociales e históricas del mismo"106, era necesario rescatar las intuiciones más valiosas de dicha teología - la primacía de la praxis y la perspectiva del pobre- dándoles un nuevo tratamiento sistemático. Entre otras cosas, esto ha llevado a González a hacer fuertes acusaciones contra ciertas expresiones teológicas y eclesiásticas de la liberación: por ejemplo, las ha acusado de constantinistas, por haber confiado desmedida -incluso violentamente- en el poder del Estado, y de soberbias, por juzgar sectariamente el crecimiento impresionante de las iglesias pentecostales entre los más pobres de la América Latina ${ }^{107}$.

Como se ve, tenemos entre España y América Latina una filosofía de la religión notablemente articulada y sistemática. Indiscutiblemente su autor fundamental es Zubiri. Las de Ellacuría y González son reinterpretaciones de las mismas ideas básicas. Pues bien: habiendo ya expuesto los problemas específicos de las filosofías de la liberación enfrentadas al hecho religioso, ahora podemos hacer afirmaciones más generales acerca de la originalidad de Zubiri y de sus seguidores frente a los modos de aproximación filosófica que han predominado en aquellas filosofías ${ }^{108}$. Uno de aquellos modos es el fenomenológicohermenéutico, presente en autores latinoamericanos a través de las figuras de Heidegger, Lévinas y Ricoeur. Podemos decir, en principio, que el análisis del hecho radical de la religación es anterior al análisis del logos (del sentido) religioso. En el fondo, es la prioridad del análisis frente a la comprensión y a la explicación. De ahí que Zubiri pueda entregar una definición universal de religión. Una definición en la que no se imponga la propia concepción de la religión a

\section{5}

Sobre la fllosolía de la religión en América Latina 
otras tradiciones religiosas. El procedimiento de Zubiri exhibe, por esto mismo, una cierta neutralidad hermenéutica, pues el estudio de la religación no requiere una especial sensibilidad religiosa del estudioso. Es un método, además, que posee la ventaja comparativa de respetar la peculiaridad de lo religioso, justamente porque no intenta reducirlo a procesos sociológicos o psicológicos. Con todo, no hay que perder de vista que la fenomenología hermenéutica es un legítimo análisis de los logoi religiosos, aunque posterior al análisis del hecho de la religación ${ }^{109}$.

Zubiri también puede admitir, enseguida, que los métodos críticoexplicativos, a los que recurren, sobre todo, las corrientes marxistas, son perfectamente legítimos. Si no lo fueran, las consecuencias serían rocambolescas. No sólo deberíamos declarar como reducciones ilegítimas de los hechos religiosos a las críticas psicológicas o sociológicas de la religión, sino que también tendríamos que aceptar la ilicitud de toda hipótesis teísta, es decir, de todo intento de fundamentar el hecho de la religación en la realidad de Dios. Veamos por qué. Para Zubiri, la razón, al encontrar un fundamento, nunca está segura de que ese fundamento sea el único posible: las distintas explicaciones del hecho religioso pueden ser compatibles entre sí. El problema, entonces, radica en la pretensión de exclusividad de una determinada explicación, como es el caso de la marxista o de la freudiana. Ambas pueden ser estupendas explicaciones de las funciones sociales o psicológicas de la religión. Pero eso es algo que habrá que determinar caso por caso, recurriendo a la experiencia. Esto nos lleva al problema de la experiencia religiosa, un asunto profusamente estudiado ya desde la obra clásica de James sobre Las variedades de la experiencia religiosa. Hemos de preguntarnos, al menos, en qué consiste y cómo se verifica dicha experiencia religiosa. Pudiéramos decir que, según Zubiri, esta experiencia es la probación física y real de un esbozo teísta racionalmente postulado por su inserción en la vida humana (en sus dimensiones individual, social e histórica). Una tal probación consiste no sólo en la conformación de la vida humana de acuerdo al fundamento divino postulado, sino, sobre todo, en la compenetración íntima de ella -en esa entrega de la propia persona que es la fe-con esa misma realidad-fundamento. Por esto mismo, Zubiri no parecería aceptar una cierta concepción de la verificación histórica según la cual la religión sería primo et per se una cosmovisión de la totalidad de la

\section{6}

Realidad 103, 2005 
realidad y la historia que se justificaría por su rendimiento hermenéutico (como piensa Pannenberg). La verificación religiosa, en realidad, sólo puede ser concreta, y consiste en la realización personal de la fundamentación religiosa del hecho de la religación (como lo vislumbró Bonhoeffer): "si bien no podemos tener experiencia de Dios, sí podemos ser experiencia de Dios, viviendo nuestra vida ligados a Aquél que hemos postulado como el fundamento último del poder de lo real" 110 .

En suma: la de Zubiri y sus continuadores no es una fenomenologíahermenéutica, ni una crítica-explicativa de la religión. Es, más bien, una peculiar fenomenología de la religión que analiza (1) el hecho primordial de la religación, (2) los logoi religiosos, y (3) la razón religiosa. Siendo los análisis lógicos (2) y racionales (3)' estructuras ulteriores radicadas en (1) el hecho total y absoluto de la religación, que es la estructura primaria y radical ${ }^{111}$.

3. Estas ventajas de la filosofía fenomenológica de la religión nos conducen por último al problema fundamental: ¿está justificada la apelación a la fenomenología? Me refiero a una forma de fenomenología no idealista ni hermenéutica. Digo esto con todo el respeto del mundo por el idealismo y la hermenéutica. Pero pienso que las mejores posibilidades de la fenomenología, en general y de cara a la religión, suponen una renuncia en el comienzo de la filosofía a ciertas adherencias idealistas y hermenéuticas. Dicho de otro modo, apelo a la fenomenología como filosofía para la cual el principio de todos los principios supone la crítica más radical que sea posible de cualquiera clase de presupuestos. Desde esta perspectiva, la fenomenología es la pretensión de hacer filosofía sin supuestos.

Sin embargo, ino es ingenua esta pretensión de hacer filosofía sin supuestos? ¿Acaso no cargamos constantemente con un cúmulo de presuposiciones de las que nunca podremos prescindir críticamente? ${ }^{112}$. $\mathrm{Y}$ además, ¿puede argumentarse a favor de una filosofía que sea pura filosofía y que no se gane de inmediato el reproche de conservadora o, al menos, de carecer de compromiso mundanal? ¿No son primeras para el ser humano sus opciones fundamentales ante la realidad, la historia y su propia vida, y siempre y sólo secundaria la articulación reflexiva de estas opciones en que consiste la filosofía? ${ }^{113}$. 
Partiendo por esto último, no creo que para proceder correctamente en filosofía haya que ser especialmente sensible a los reproches de conservadurismo o progresismo. En filosofía las etiquetas sobran. Reconozco que dentro del selecto grupo de las filosofías excelentes, unas son más bien de derechas, otras más bien de izquierdas. Empero, lo que prima por doquier es lo pésimo y lo mediocre. El mundo es ancho y ajeno, y está superpoblado de ejemplares perfectamente prescindibles de filosofías conservadoras y progresistas. Pienso, en síntesis, que la orientación política de una filosofía no es suficiente garantía de su calidad. Y que para satisfacer la pretensión filosófica de una posición política se necesitan altos grados de rigor, precisión y responsabilidad intelectual. Si se me permite una comparación literaria, diría que para un filósofo es mil veces preferible el modelo de Kafka que el de García Márquez o el de Vargas Llosa: podríamos aprender mucho más del escritor frágil, asustadizo, oculto y gris, pequeño, perplejo, lleno de silencio y humanidad, que de esos escritores seguros de sí mismos, consejeros de príncipes y sermoneadores públicos, tajantes portavoces de una redención indudable.

$Y$ en cuanto a la ilusión de proceder sin supuestos, pienso que Husserl tenía razón: es posible distinguir entre lo que se nos da originariamente y la interpretación de esos datos. Claro es que inevitablemente interpretamos eso que se nos hace presente. Más aún, también es claro que la interpretación misma es una tarea plagada de presupuestos de toda índole. Pero lo decisivo radica en que contamos con un criterio para discernir la corrección de una determinada interpretación y para criticar las presuposiciones injustificadas envueltas en ella. Ese criterio transciende a la interpretación y consiste en la presencia originaria de las cosas en nuestra existencia. Ellas son las que nos permiten avanzar en la penosa e inacabable faena de interpretar. $Y$ es que pulir una interpretación es, en realidad, una tarea que sólo se cumple por aproximación. El mejor ajuste de una interpretación para con los datos originarios está gobernado por el ideal de un ajuste pleno y adecuado que jamás se alcanzará. En este sentido, todo análisis fenomenológico es imperfecto y mejorable, pero es a la vez posible y primero. Aquí volvemos a encontrarnos con la idea de una filosofía primera. Ése fue justamente el empeño de Aristóteles, Descartes y Husserl. 


\section{BIBLIOGRAFÍA}

Beorlegui, Carlos (1997), "La influencia de E. Lévinas en la filosofía de la liberación de E. Dussel y de J. C. Scannone", en Realidad. Revista de ciencias sociales y bumanidades, 57/58, pp. 243-273 y 347-372.

(2003), "El problema de las filosofías nacionales", en Información filosófica. Revista internacional de filosofía y ciencias bumanas II/1, pp. 5-22.

(2004), Historia del pensamiento filosófico latinaomericano.

Una buisqueda incesante de la identidad (Universidad de Deusto, Deusto).

Berger, Peter (1981), Para una teoría sociológica de la religión (trad. M. Montserrat y V. Bastos Kairós, Barcelona).

Boff, Clodovis (1993), "Epistemología y método de la teología de la liberación", en Mysterium liberationis (UCA, San Salvador $3^{a}$ ed. [1990]), pp. 79-113.

Coetzee, John M. (2004), Elizabeth Costello (trad. J. Calvo, Mondadori, Barcelona [2003]).

Cullen, Carlos (1984), "Fenomenología y sabiduría popular", en Scannone, Juan Carlos (ed.), Sabiduría popular, simbolo y filosofía. Diálogo internacional en torno de una interpretación latinoamericana (Guadalupe, Buenos Aires), pp. 27-43.

Dussel, Enrique (1977), Religión (Edicol, México).

1980), Filosofía ética latinoamericana V. Arqueológica latinoamericana: una filosofía de la religión antifetichista (Universidad Santo Tomás, Bogotá).

Mysterium liberationis (UCA, San Salvador $3^{\text {a }}$ ed [1990]), Pp. 115 144.

(1995), Introducción a la filosofía de la liberación (Nueva América, Colombia $5^{\mathrm{a}}$ ed. [1979]).

. (2001), "Religiones mundiales y secularización desde una perspectiva post-colonial y anti-eurocéntrica", en Hacia una filosofía política crítica (Desclée de Brouwer, Bilbao [2000]), pp. 409-422. 
Ellacuría, Ignacio (2000a), "La religación, actitud radical del hombre", en Escritos teológicos. I (UCA, San Salvador [1966]), pp. 39-105. tiana?”, en Escritos teológicos. I (UCA, San Salvador [inédito]), pp. 509-516.

(2000c), "Historia de la salvación y salvación en la historia”, en Escritos teológicos. I (UCA, San Salvador [1973]), pp. 519533.

(1993), "Función liberadora de la filosofía", en Escritos políticos. I (UCA, San Salvador $2^{a}$ ed. [1985]), pp. 93-121.

dor).

. (1990), Filosofía de la realidad histórica (UCA, San Salva-

Fornet-Betancourt, Raúl (1988), Philosophie und Theologie der Befreiung (Materialis, Frankfurt).

. (1992), "La filosofía de la liberación en América Latina", en Estudios de filosofía latinoamericana (UNAM, México), pp. 85108. de Brouwer Bilbao).

González, Antonio (1999), Teologia de la praxis evangélica (Sal Terrae, Santander).

(2004), "Aproximación a la filosofía zubiriana de la religión”, en Nicolás, J. y Barroso, O. (ed.), Balance y perspectivas de la filosofia de X. Zubiri (Comares, Granada), pp. 265-282.

Kusch, Rodolfo (1999), América profunda (Biblos, Buenos Aires $4^{\mathrm{a}}$ ed. [1962]). [1966]).

(1994), Indios, porteños y dioses (Biblos, Buenos Aires (1970), El pensamiento indígena americano (Cajica, Puebla [la $3^{\text {a }}$ ed. de 1977 , que no altera el texto original, lleva el título El pensamiento indígena y popular en América]).

. (1973), "Una lógica de la negación para comprender a América”, en VV.AA., Hacia una filosofía de la liberación latinoamericana (San Pablo/Bonum, San Salvador/Buenos Aires), pp. 178-186. 
(1976), Geocultura del hombre americano (F. García Cambeiro, Buenos Aires).

Scannone, Juan Carlos (1976a), "El Dios de la historia y la praxis de liberación. I. El itinerario filosófico hacia el Dios vivo: historia, planteo actual y relectura desde la situación latinoamericana", en Teologia de la liberación y praxis popular. Aportes críticos para una teología de la liberación (Sígueme, Salamanca [1974]), pp. 187-216.

. (1976b), "El Dios de la historia y la praxis de liberación II. Trascendencia, praxis liberadora y lenguaje (hacia un lenguaje teológico posmoderno y latinoamericanamente situado", en Teología de la liberación y praxis popular. Aportes críticos para una teología de la liberación (Sígueme, Salamanca [1973]), pp. 217-252.

. (1987), Teología de la liberación y doctrina social de la iglesia (Cristiandad, Madrid/Buenos Aires).

. (1990a), "Sabiduría popular y pensamiento especulativo", en Scannone, J. C., Nuevo punto de partida en la filosofía latinoamericana (Guadalupe, Buenos Aires [1984]), pp. 43-73.

. (1990b), "Mestizaje cultural': categoría teórica fecunda para interpretar la realidad latinoamericana", en Scannone, J. C., Nuevo punto de partida en la filosofía latinoamericana (Guadalupe, Buenos Aires [1977]), pp. 172-187.

. (1990c), "Religión, lenguaje y sabiduría de los pueblos", en Scannone, J. C., Nuevo punto de partida en la filosofía latinoamericana (Guadalupe, Buenos Aires [1978]), pp. 205-221.

. (1990d), "Simbolismo religioso y pensamiento filosófico según Paul Ricoeur", en Scannone, J. C., Nuevo punto de partida en la filosofía latinoamericana (Guadalupe, Buenos Aires [1980]), pp. 222235.

. (1990e), "Breves reflexiones sobre la mediación simbólica”, en Scannone, J. C., Nuevo punto de partida en la filosofía latinoamericana (Guadalupe, Buenos Aires [1986]), pp. 236-239.

bertad", (1990), "Sínbolo religioso, pensamiento analógico y libertad”, en Scannone, J. C., Nuevo punto de partida en la filosofía latinoamericana (Guadalupe, Buenos Aires [1989]), pp. 240-246. 
. (1993), "Liberación. Un aporte original del cristianismo latinoamericano", en Gómez Caffarena, J. (ed.), Religión. Enciclopedia Iberoamericana de Filosofía. 3 (Trotta, Madrid), pp. 93-105.

Solari, Enzo (2004), "La teología social de Antonio González", en Schickendantz, C. (ed.), Culturas, religiones e iglesias. Desafíos de la teología contemporánea (Editorial de la Universidad Católica de Córdoba, Córdoba), pp. 41-70.

Wuchterl, Kurt (1999), Methoden der Gegenwartsphilosophie. Rationalitätskonzepte im Widerstreit (Paul Haupt, Bern/Stuttgart/Wien $3^{\text {a }}$ ed. [1977]).

Zea, Leopoldo (1993), "Negritud e indigenismo", en Zea, L. (ed.), Fuentes de la cultura latinoamericana. III (FCE, México), pp. 355367.

Zirión, Antonio (2003), Historia de la fenomenología en México (Jitanjáfora Morelia Editorial, Morelia).

Zubiri, Xavier (1988), El hombre y Dios (Alianza, Madrid).

(Alianza, Madrid).

(1993), El problema filosófico de la bistoria de las religiones (1997), Cristianismo (Alianza, Madrid).

\section{Notas}

1. Ésta es la opinión de Scannone (1993: 98), quien piensa que estas dos vertientes no son necesariamente excluyentes. Pero es también la de Fornet-Betancourt (1988: 65-85, esp. 72; 1992: 96-97). Ciertamente existen otras clasificaciones posibles; por todos, vid. Beorlegui (2004: 666-700, esp. 695-700). Hago notar que las versiones culturalistas extremas llegan a rechazar que las suyas sean 'filosofías de la liberación'; vid. Kusch (1976: 151-152).

2. Dussel (1977: 11). Constatemos, de paso, que hay un capítulo entero de este libro de Dussel sobre la religión (1977: 11-66) que se repite, como apéndice primero, en un libro posterior del mismo autor (1980: 99-126).

3. Dussel (1977: 11-12).

4. Dussel (1977: 67-155).

5. Se trata del capítulo II de la segunda parte de Lectura materialista del Evangelio de Marcos (Verbo Divino, Navarra 1975), pp. 131-140.

6. Dussel (1977: 157-278).

7. Y no tanto en etapas más tempranas de Marx o en otras tradiciones marxistas, como ha sido la regla en las diversas teologías de la liberación: Dussel (1993: 124-132). 
8. Dussel (1993: 115, 121-123, 143).

9. Dussel (1993: 132-141).

10. Dussel (1977: 35).

11. Dussel (1977: 58).

12. Dussel (1980: 35).

13. Dussel (1980: 59).

14. Dussel (1980: 127-140). La contraposición de esos tipos ideales es tajante: contra el fetichismo, que es el dios del sistema, se afirma una y otra vez el Absoluto alterativo que se manifiesta a través del pobre, el Otro absolutamente absoluto (Dussel, 1995: 218-220). Esta perspectiva se mantiene en los últimos textos de este autor; vid. Dussel (2001).

15. Dussel (1980: 52).

16. Dussel (1980: 55).

17. Dussel (1980: 56).

18. Berger (1981: 123-150, esp. 132-149).

19. Dussel (1993: 120, 126, 136, 140-141).

20. Dussel (1993: 141-142 y 144 n. 140).

21. "En la teología de la liberación el marxismo no es nunca tratado por sí mismo, sino siempre a partir y en función de los pobres. Situado firmemente al lado de los humildes, el teólogo interroga a Marx: '¿Qué puedes decirnos tú de la situación de miseria y de los caminos para su superación?'. Aquí se somete al marxista al juicio del pobre y de su causa, y no lo contrario [...]. Por eso la teología de la liberación se sirve del marxismo de modo puramente instrumental. No lo venera como venera a los santos evangelios. Ni tampoco se siente obligada a dar cuenta a nadie del uso que hace de las palabras e ideas marxistas ( $\mathrm{si}$ las usa correctamente o nọ), a no ser a los pobres y a su fe y su esperanza. Para ser más concretos, digamos aquí que la teología de la liberación utiliza libremente del marxismo algunas 'indicaciones metodológicas' que se han revelado fecundas para la comprensión del mundo de los oprimidos [...]. Por eso también el teólogo de la liberación mantiene una relación decididamente crítica frente al marxismo. Marx (como cualquier otro marxista) puede sin duda ser compañero de camino [...], pero jamás podrá ser 'el' guía. 'Porque uno solo es vuestro guía, Cristo' (Mt 23,10) [...]. A partir del horizonte más amplio de la fe el marxismo queda radicalmente relativizado y superado en principio": Boff (1993: 103-104). Una opinión similar es la de Ellacuría (2000b: 515-516). Puede verse una aproximación fecunda, crítica al marxismo, a la vez filosófica y teológica, exenta ya de apelaciones dramáticas, en González (1999: 75-76, 82 п. 34, 160, 163 n. 100, 391 n. 144, etc.); sin embargo, en alguna oportunidad este mismo autor ha atribuido al marxismo cualidades teóricas exorbitantes en el campo de la economía: vid. Solari (2004).

22. Kusch (1976: 156)

23. Kusch (1999: 19-20; vid. Kusch 1973).

24. Kusch (1970: 14). “[...] Es preciso, especialmente aquí en América, incurrir en la grave falta de contradecir los esquemas a los cuales estamos apegados [...]. No se puede iniciar el rescate de un pensamiento incaico, por ejemplo, con una actitud filosófica enredada aún en el sistema de Comte de hace cien años, o con una fenomenología estudiada sólo como para repetirla en la cátedra": Kusch 
(1970: 15-16). Sobre el academicismo y el enciclopedismo, vid. Kusch (1970: 17-24; 1976: 10-24).

25. "Personalmente creo que ni la universalidad, ni la filosofía tal como se entiende en Occidente, interesa mucho en este rescate de un pensamiento autóctono. Esto último, por su parte, tiene una finalidad mucho más universal de lo que un catedrático occidentalizado puede suponer": Kusch (1970: 23 n. 6). Su finalidad, en último término, no es una parcela humana, sino el "hombre total", "una visión total del puro fenómeno del hombre": Kusch (1994: 121-122; vid. 1976: 44-46).

26. Kusch (1970: 24; vid. 1976: 71).

27. Kusch (1999: 23-24; vid. 1994: 109; 1976: 63-65, 126-135). Por esto mismo es por lo que "la búsqueda de un pensamiento indígena no se debe sólo al deseo de exhumarlo científicamente, sino a la necesidad de rescatar un estilo de pensar que, según creo, se da en el fondo de América y que mantiene cierta vigencia en las poblaciones criollas" (1970: 9).

28. Kusch (1970: 10). "¿Cuándo comprenderemos que la clave no está en arreglar a América, sino en someternos a ella, adquirir el plan de vida que le es implícito?": Kusch (1994: 123). De esto se deriva que "un pensamiento seminal humaniza el hábitat en que se vive, de tal modo que asumir en Sudamérica una posición liberal o comunista no es más que prender velas a un mismo santo disfrazado de distinta manera” (1970: 323). Sobre posturas democráticas o marxistas, que representarían el típico "sentir de la clase media" o la habitual "visión del mundo que implica la clase media”, vid. Kusch (1994: 43, 81, 109, 112 y 115-126; 1976: 11 y $70-71)$.

29. Kusch (1970: 267; vid. 293). Esto lleva a Kusch a destacar el cúmulo de problemas envueltos en la investigación del hombre americano. Quizá el más acuciante de todos sea el de salvar el "vacío intercultural" entre estudiosos occidentalizados y grupos investigados que pertenecen a otra cultura y despliegan otra racionalidad. Kusch piensa que la única manera de transcender esa "tierra de nadie" ("un vacío sin significado, imposible de determinar por falta de símbolos") consiste en "superar el modelo o la figura del imperio". Y una manera concreta de hacerlo radica en "la posibilidad de una Antropología Filosófica Americana" -que alcanzó a ser esbozada por Kusch en 1978-, prosiguiendo à la americana la reflexión sobre la finitud de Heidegger, Foucault y Ricoeur (1976: 140-142, en gral. 136-142). Sobre el problema filosófico de la interculturalidad en Iberoamérica, vid. los numerosos trabajos de Fornet-Betancourt (por ej. 2001).

30. Kusch (1970: 242-268 y 288-310; 1976: 33 y 75). En verdad, Kusch piensa que la de América no es pura y simple irracionalidad, sino más bien otra racionalidad, "una racionalidad más profunda, o mejor, más próxima a nuestros conflictos" (1976: 136).

31. Kusch (1999: 158; vid. 1970: 12 y 381; 1994: 22, 91, 95, 107-108; 1976: 30 y 37). De ahí la necesidad filosófica sentida en América de "una hermenéutica de lo pre-óntico", de un examen simbólico de ese "estrato realmente pre-ontológico" que es el "vivir puro" (1976: 148 y 157). Aquí emerge ya la idea de 'estar'.

32. Kusch (1999: 92-95; vid. 101-134; 1970: 294).

33. Kusch (1999: 92-95; 1994: 18).

34. Kusch (1999: 24-26; vid. 97; 1994: 72-76). 
35. Kusch (1999: 20).

36. Kusch (1999: 124-125; vid. 1994: 37-38 y 96-98; 1970: 355-367; 1976: 18-22, 26-34, 115, 134, 150-151).

37. Kusch (1970: 13 ; vid. 1973: 180 y 185; 1994: 122-124).

38. Kusch (1999: 148-149; vid. en gral. 21, 29, 148-150).

39. Kusch (1999: 89-91).

40. Kusch (1999: 90 n. 72 y 91 n. 73). Y es que ser, desde Grecia hasta hoy, ha significado - como ha dicho Ortega- lo activo, lo ejecutivo de la existencia. Toda la filosofía occidental, en verdad, ha sido una filosofía del ser: Kusch (1999: 91; vid. en gral. 90-91). En el propio Heidegger falta un previo examen filosófico de la vida, de ése su 'no-ser' o 'estar-siendo', "del 'estar' como horizonte autónomo" (1976: 154; vid. 153-158).

41. Kusch (1999: 33). Hay, pues, un miedo terrible del indígena, que "no es más que una consecuencia de llevar el inconsciente a flor de piel con una intensidad angustiosa que el ciudadano no conoce [...]. El montaje de la cultura de ciudad responde a esa necesidad de cubrir el inconsciente mediante toda clase de elementos conscientes [...]. Pero esto mismo constituye una ventaja, porque el indígena sorbe de ahí mismo la necesidad de una fe y de un mito, o sea, la clave de la andanza del dios por el mundo en ese margen en el que lindan hombre y mundo, vida y muerte, luz y noche, conciencia e inconciencia. Es un dios que ejerce un poderío mágico sobre el mundo, siendo éste lo maldito, la pesadilla o, como piensa el yamqui, el "hervidero espantoso"': Kusch (1999: 47).

42. Kusch (1999: 97; vid. 31-35, 68, 76). Kusch se detiene en el episodio de Atahualpa y el padre Valverde: "éste le muestra la Biblia a aquél. Pero el inca no la entiende $y$, al rechazarla, Valverde da la señal para apresarlo". En un drama quechua anónimo - La tragedia del fin de Atawallpa- "el padre Valverde ofrece la Biblia al inca Atahualpa y éste la rechaza, diciendo 'no me dice absolutamente nada' [...]. Es indudable que el autor anónimo quiere hacer notar que Atahualpa esperaba una manifestación física de la Biblia, o sea que esperaba un sonido o una voz". "Se diría que el indio advertía que en la religión católica campeaba ya el demonio de Descartes con su intelectualismo industrioso". Kusch pasa revista a una enorme desviación del cristianismo: Carlos V, la corte española y su lucha contra la Reforma; los jesuitas; el calvinismo; la postura técnica del siglo XV y su influencia en el cristianismo; la ciudad y las clases medias europeas; el papado y sus pretensiones exorbitantes. "Lo auténtico del cristianismo primitivo fue superado, porque se dejó de creer en el dios iracundo, que aún regía hasta el siglo XIII. De ahí la expresión de Lutero en las Confesiones de Augsburgo, cuando se pronuncia abiertamente en contra de la ira divina [...]. De ahí la mentira y de ahí Valverde y de ahí, también, la simulación exasperada de una actitud inquisidora y de una religión pura, cuando en verdad no sólo en el mundo latino, sino también en el anglosajón, alentaba aún el viejo dios iracundo, el dios primitivo en quien todavía creía Atahualpa. De ahí que en el mencionado episodio el único que tenía razón era Atahualpa y en cambio estaban equivocados Valverde, España y aun la misma Europa. Indudablemente el único que sabía era Atahualpa. Él esgrimía una sabiduría que pertenecía a la antigua América y que indudablemente mantuvo - y aún mantiene- su vigencia en la América actual" (1999: 96-99; vid. 1994: 59-63). De ahí que una institución como la iglesia —al 
igual que el partido político, la universidad y el estado - sea fuente de desarraigo (1976: 146).

43. Kusch (1970: 373-375).

44. Kusch (1999: 27-28).

45. Kusch (1994: 29, 89-91, 103-109; vid. 1976: 31: "oler a los dioses", "tener a los dioses a flor de piel"). Sobre el misterio sagrado, vid. Kusch (1994: 35: la calle era más sagrada que el hogar propio; 54-55: 'eso es sagrado para mí'; 64: el tono sagrado de una ofrenda; 71: "icon qué facilidad escamoteamos la puerta abierta al misterio!"; 81: mundo sagrado, personaje sagrado, palabra sagrada; 83 y 86 : el rayo y el humo como irrupciones de lo sagrado y la ausencia de sacralidad como esterilidad; 95-96: "el indio estaba con un pie en el suelo, y con el otro en lo sagrado", el citadino -en cambio- habita un universo vacío; 99: el rito, la magia y la religión comienzan por lo profano, siguen mediante el encuentro de éste con lo sagrado y acaban con el triunfo del mundo sagrado; 1976: 31: la religiosidad aymará incluye la "sacralización constante de los utensilios diarios"; 112: la referencia indígena a lo sagrado; 131: "la realidad es un acontecer de lo sagrado"; 150-151: la presión de lo sagrado y su acontecer real en el pueblo como significación reguladora del mundo y como cesación de todo acontecer, es decir, como "no obrar", pues tal "es el sentido que tiene en el fondo lo religioso para nosotros"; etc.).

46. Kusch (1994: 84).

47. Kusch (1994: 25-26). El miedo -un terror intimísimo y originario- parece estar en el origen de la proyección religiosa de los dioses; vid. Kusch (1976: 22-23). Empero, Kusch no siempre se atiene a esta idea de la proyección: "antes los dioses nos creaban a nosotros, ahora nosotros somos los dioses" (1994: 70).

48. Kusch (1994: 18 y 32; vid. 37: el indio "sabe quién hace crecer [su siembra, su vida, sus hijos, su propia muerte]; está seguro que detrás de todo están los dioses. Y éste es el sentido real de su espera"; 69: "debía ser como Viracocha y debía encontrar al dios dentro de sí mismo"; 1999: 95: "es el límite o eje que impone la ira de Jehová cuando dicta a Moisés el código moral”).

49. Kusch (1994: 63).

50. Scannone (1990a: 51 y 57; vid. en gral. 44-57). "Kusch dice que en el mito [...] Dios no 'es', sino que 'está': está en cuanto mediante los símbolos, el relato simbólico y la acción ritual, está centrando y dando fundamento al sujeto de ese relato y acción [...].": Scannone (1990a: 51). "Hablando del 'estar' intentamos con Kusch explicitar el carácter religioso (sagrado, numinoso) de ese ámbito, que no permitiría una interpretación a-tea (ni siquiera por prescindencia, como lo permitiría el pensamiento de Heidegger). El símbolo de la Pacha Mama alude a la tierra como sagrada, raíz del momento ctónico tanto de la religión como del nosotros ético-cultural": Scannone (1990a: 55; sobre la P. Mama, vid. 6768). "Los caracteres indicados de raigalidad y simbolicidad hacen que, en la comprensión del 'estar' [...] el acento no esté tanto puesto en el acontecer y en el tiempo [...], sino en el arraigo en la tierra, y, de ahí, en la espacialización originaria y originante de situacionalidad y geoculturalidad": Scannone (1990a: $56)$.

51. Scannone (1990a: 49 n. 4; 1993: 100 n. 3).

52. Cullen (1984: 40).

\section{6}

Realidad 103, 2005 
53. Vid. Kusch (1976: 136-144).

54. Kusch (1999: 182; vid. 1976: 71).

55. Kusch (1999: 161-162; vid. 1994: 46-47 y 78-79: la ciencia "no es más que el invento de los débiles que siempre necesitan una dura realidad ante sí, llena de fórmulas matemáticas y deberes impuestos").

56. Kusch (1999: 159, 285 y 339). Vid. Kusch (1994: 120, 123; 1976: 11-12, 14, 31, $62,104-105,125,132,150,157)$.

57. Kusch (1999: 37 n. 8).

58. Kusch (1999: 76).

59. Kusch (1999: 82-83). Advirtamos que esta misma afirmación no debe poco a las reflexiones de Lévy-Bruhl sobre la mentalidad prelógica (1999: 88).

60. Kusch (1999: 32 n. 5, 47 n. 20, 54 n. 31, 56 n. 35, 60 n. 41, 82 n. 62, 92, 114 n. 20; 1970: 23 n. 9,72 n. 1,81 n. 7,230 n. 16, 250, 253-255, 266-267, 295-296, 372; 1976: 44-45, 73; etc.).

61. Kusch (1970: 11; vid. 1976: 31-32, 63-64, 82-84, 101, 112, 148).

62. Zea (1993: 365-366). Vid. Kusch (1976: 11).

63. Coetzee (2004: 53, 57-58 y 60).

64. En Der Gott der Philosophen (Darmstadt 1971), pp. 11ss.

65. Scannone (1976a: 199-207, esp. 199 y 206; 1990f: 240-241 y 245-246).

66. Scannone (1976b: 219 n. 2 y 239 n. 23 ).

67. Scannone (1990f: 241).

68. Scannone (1976a: 191-207; 1976b: 220-236). En esta revisión histórica Scannone también menciona a Maréchal y su escuela (1976a: 194-195, 199-200, 205 nn. 17 y 18). Respecto de la influencia de Lévinas en Scannone y en Dussel, vid. Beorlegui (1997; 2003: 19-20).

69. Scannone (1976a: 208).

70. Scannone (1976b: 238-239).

71. Scannone (1976b: 239-240).

72. Scannone (1976b: 241 y 245-246).

73. Scannone (1976a: 197 y 202).

74. Scannone (1976a: 209-212).

75. 'Así es que las categorías 'revolución', 'dependencia', 'socialismo', etc., se desunivocizan": Scannone (1976b: 247). Según este autor, lo novedoso del pensamiento filosófico y teológico latinoamericano centrado en la liberación radica en el "replanteamiento de la relación entre religión (en especial, cristiana) y liberación bumana. Por un lado, se acepta la contribución de la crítica de las ideologías a la comprensión auténtica de la religión; por otro lado, se entiende la liberación en toda su radicalidad e integralidad, como religiosa, ética $e$ bistórica (política, social, económica, cultural, etc.) y se enfatiza el nexo intrínseco entre ambas": Scannone (1993: 102).

76. "Así se llega a descubrir toda la implicancia secular, política y aun revolucionaria de palabras como 'Dios', 'pecado', 'salvación', 'fe', 'esperanza', etc., cuando se veri-fican en una praxis histórica de liberación que surge desde la transcendencia y a ella se abre": Scannone (1976b: 247).

77. Scannone (1976a: 212-214).

78. Scannone (1976b: 250).

79. Scannone (1990a: 60). 
80. Scannone (1990c: 206).

81. Scannone (1990e: 239). Sobre la relación de la religión con el símbolo, la analogía y la sabiduría popular, vid. Scannone (1990a: 58-73; 1990b; 1990d; 1990e). Nótense, en estas cuestiones, las frecuentes alusiones a Ricoeur (vid., por ej. 1976a: 214 n. 23; 1990a: 49-50, 54, 56-57, 59 n. 12, 62 n. 15, 69-70; 1990d; etc.).

82. Scannone (1976a: 216 n. 24). Scannone establece la filiación de la expresión y la define como "una analogía que asume, purifica, transforma y supera la dialéctica", y también como "una dialéctica abierta a la transcendencia, la gratuidad y la novedad histórica, pensada según el ritmo y la estructura de la analogía tomista" (1987: 18 y 1990b: 186 n. 20; vid. 1976a: 216 n. 24). Dussel también usa esta expresión, pero en un sentido distinto.

83. Scannone (1976b: 252).

84. Scannone (1976b: 251).

85. Scannone (1990a: 67; 1990f).

86. Scannone (1990f: 243 ).

87. Scannone (1990f: 245).

88. Por ej., Beorlegui (2004: 663, 700 y 807).

89. Beorlegui (2004: 492, 405-407 y 489-496, respectivamente).

90. Beorlegui (2004: 523).

91. Beorlegui (2004: 531-533).

92. Vid. Beorlegui (2004: 779-791; vid. también 846-847).

93. Se lo menciona, sí, como discípulo de Ellacuría; vid. Beorlegui (2004: 785791). La justificación de esta omisión radicaría en la juventud y en el carácter todavía abierto de su obra (2004: 803-804).

94. El caso mexicano es uno de los mejor estudiados entre nosotros; vid. Zirión (2003).

95. Zubiri (1988: 75-112).

96. Zubiri (1988: 369-371).

97. Zubiri (1993).

98. Zubiri (1993: 251-252 y 257; 1997: 16-19 y 614-617).

99. Zubiri (1993: 330, 210, 332 y 338, respectivamente).

100. Ellacuría (2000a y 1990: 599-602).

101. Ellacuría (1990: 15-47).

102. Ellacuría (1990: 600-601).

103. Ellacuría (2000c: 533).

104. González dice que los sentidos religiosos, por muy generales que sean (como el de lo sagrado), no siempre son aplicables a todas las experiencias religiosas. El problema radicaría en que siempre necesitamos de un criterio para distinguir los sentidos religiosos de los que no lo son. Zubiri parece pensar, por el contrario, que lo sagrado sí es un sentido suficientemente general y que, en principio, podría abarcar la multiforme experiencia religiosa de la humanidad. La sacralidad sería un sentido consecutivo al hecho religioso, pero que lo recubriría. Si todo lo religioso es sagrado, lo es justamente por ser religioso. $Y$ si una cierta plasmación de la religación es religiosa, su manifestación ante el logos será sagrada. Ésta sería la única forma de tener alguna certeza acerca del 
carácter religioso de un determinado sentido. La sacralidad sería, pues, la ratio cognoscendi de la religión. Vid. Zubiri (1993: 24-28).

105. González (1999: 127-141).

106. González (1999: 13).

107. Vid. Solari (2004).

108. Aquí seguiré de cerca a González (2004).

109. González (2004: 266-270). No está de más advertir, contra lo que parece decir González, que no toda fenomenología coincide con las hermenéuticas radicales. Sí ha de concederse, primero, que la de Husserl es una fenomenología idealista centrada en los procesos de constitución de sentido ante un yo transcendental. Y segundo, que las fenomenologías y las hermenéuticas de la religión más conocidas tienden a ser comprensión del sentido religioso; piénsese sólo en van der Leeuw, en Eliade y en Ricoeur.

110. González (2004: 273-277).

111. González (2004: 281-282).

112. Para una buena síntesis de esta crítica a la fenomenología, desde el punto de vista del racionalismo crítico, la hermenéutica, el psicoanálisis y la teoría crítica, vid. Wuchterl (1999: 213-223, esp. 213-215 y 221-223).

113. Ellacuría insinúa esta cuestión, aunque matizándola al invocar el carácter críticamente liberador y fundamentador que es intrínseco a la filosofía (vid. 1993). 